\title{
Glacier Physics of the Puget Lobe, Southwest Cordilleran Ice Sheet
}

\section{La physique glaciaire du lobe de Puget, au sud-ouest de l'Inlandsis de la Cordillère}

\section{Glaziale Physik des Puget-Lappens, südwestliche Kordilleren-Eisdecke}

\author{
Derek B. Booth
}

Volume 45, numéro 3, 1991

L'Inlandis de la Cordillère

The Cordilleran Ice Sheet

URI : https://id.erudit.org/iderudit/032877ar

DOI : https://doi.org/10.7202/032877ar

Aller au sommaire du numéro

Éditeur(s)

Les Presses de l'Université de Montréal

ISSN

0705-7199 (imprimé)

1492-143X (numérique)

Découvrir la revue

Citer cet article

Booth, D. B. (1991). Glacier Physics of the Puget Lobe, Southwest Cordilleran Ice Sheet. Géographie physique et Quaternaire, 45(3), 301-315.

https://doi.org/10.7202/032877ar
Résumé de l'article

Le lobe de Puget, à la limite sud-ouest de l'Inlandsis de la Cordillère, permet d'étudier les liens entre la physique glaciaire et l'action glaciaire. L'action de l'eau à proximité et à l'intérieur des sédiments du lit glaciaire est un aspect particulièrement important de la géologie de l'inlandsis. Les données d'ordre physique et les calculs du bilan de masse permettent de faire une reconstitution assez fidèle du lobe et d'extrapoler les vitesses de glissement au delà de $500 \mathrm{~m} / \mathrm{a}$ et les débits d'eau de près de $1 * 10$ " m3/a. L'écoulement de l'eau sous-glaciaire a créé un réseau de chenaux dentritiques que l'analyse statique de l'hydrologie sous-glaciaire a extrapolé avec justesse. Près de la marge glaciaire orientale, un important chenal isolé a assuré épisodiquement le drainage sous-glaciaire, alors que les lacs de barrage glaciaire emprisonnés dans les vallées adjacentes se déchargeaient par débâcles. L'eau de fonte basale a produit des pressions d'eau près de l'équilibre hydrostatique et de très faibles résistances du till à la base de l'inlandsis. La pression de l'eau ne diminuait que près de la marge glaciaire, laissant ainsi les taux de contrainte normaux s'élever jusqu'à des proportions importantes de la couverture totale de glace. Ainsi les conditions du lit sont très différentes selon qu'il se situe en zone interne ou en zone marginale. L'observation des dépôts sous-glaciaires révèle la phase finale en zone marginale, mais les conditions à l'intérieur même de l'inlandsis, d'une plus grande portée quant à l'évolution et au comportement du glacier, pourraient être très différentes.
Tous droits réservés @ Les Presses de l'Université de Montréal, 1991
Ce document est protégé par la loi sur le droit d'auteur. L’utilisation des services d’Érudit (y compris la reproduction) est assujettie à sa politique d'utilisation que vous pouvez consulter en ligne.

https://apropos.erudit.org/fr/usagers/politique-dutilisation/ 


\section{GLACIER PHYSICS OF THE PUGET LOBE, SOUTHWEST CORDILLERAN ICE SHEET}

Derek B. BOOTH, King County Basin Planning, 770 Dexter Horton Building, Seattle, Washington 98104, U.S.A. and Department of Geological Sciences, University of Washington AJ-20, Seattle, Washington 98195, U.S.A.

\begin{abstract}
The Puget lobe, the southwestmost extension of the Cordilleran ice sheet, provides an excellent opportunity to examine the connection between glacier physics and the resulting products of glaciation. The action of water, at and within the sediments of the glacier bed, is particularly significant for the geologic record of this ice sheet. Physical data and inferred mass balance relationships constrain lobe reconstruction and predict sliding velocities in excess of $500 \mathrm{~m} / \mathrm{a}$ and water discharges of nearly $1 \times 10^{11} \mathrm{~m}^{3} / \mathrm{a}$. This subglacial water produced a dendritic channel pattern well predicted by static analysis of subglacial hydrology. Near to the eastern ice margin, a much larger single channel drained subglacially and episodically, with tributary icedammed lakes releasing their water as jokulhlaups. Basal meltwater generated nearhydrostatic water pressures and very low till strengths at the base of the ice sheet. Water pressure dropped only close to the ice margin, allowing normal stresses to rise to significant fractions of the total ice overburden. Thus marginal and interior zones impose contrasting bed conditions. Although observation of subglacial deposits will reflect the late-stage passage of the marginal zone, conditions within the ice-sheet interior, far more significant to glacier history and behavior, may be substantially different.
\end{abstract}

RÉSUMÉ La physique glaciaire du lobe de Puget, au sud-ouest de I'Inlandsis de la Cordillere. Le lobe de Puget, à la limite sudouest de l'Inlandsis de la Cordillère, permet d'étudier les liens entre la physique glaciaire et l'action glaciaire. L'action de l'eau à proximité et à l'intérieur des sédiments du lit glaciaire est un aspect particulièrement important de la géologie de l'inlandsis. Les données d'ordre physique et les calculs du bilan de masse permettent de faire une reconstitution assez fidèle du lobe et d'extrapoler les vitesses de glissement au delà de $500 \mathrm{~m} / \mathrm{a}$ et les débits d'eau de près de $1 \times 10^{11} \mathrm{~m}^{3} / \mathrm{a}$. L'écoulement de l'eau sous-glaciaire a créé un réseau de chenaux dentritiques que l'analyse statique de l'hydrologie sous-glaciaire a extrapolé avec justesse. Près de la marge glaciaire orientale, un important chenal isolé a assuré épisodiquement le drainage sous-glaciaire, alors que les lacs de barrage glaciaire emprisonnés dans les vallées adjacentes se déchargeaient par débâcles. L'eau de fonte basale a produit des pressions d'eau près de l'équilibre hydrostatique et de très faibles résistances du till à la base de l'inlandsis. La pression de l'eau ne diminuait que près de la marge glaciaire, laissant ainsi les taux de contrainte normaux s'élever jusqu'à des proportions importantes de la couverture totale de glace. Ainsi les conditions du lit sont très différentes selon qu'il se situe en zone interne ou en zone marginale. L'observation des dépôts sous-glaciaires révèle la phase finale en zone marginale, mais les conditions à l'ìntérieur même de l'inlandsis, d'une plus grande portée quant à l'évolution et au comportement du glacier, pourraient être très différentes.
ZUSAMMENFASSUNG Glaziale Physik des Puget-Lappens, südwestliche Kordilleren-Eisdecke. Der Puget-Lappen, die südwestliche Ausdehnung der KordillerenEisdecke, bietet eine ausgezeichnete Gelegenheit, die Beziehung zwischen glazialer Physik und den daraus resultierenden Produkten der Vereisung zu untersuchen. Die Wirkung von Wasser in der Nähe der Sedimente des Gletscherbettes und in ihnen ist besonders signifikant für die geologische Dokumentierung der Eisdecke. Physikalische Daten und abgeleitete MassenbilanzBeziehungen erlauben eine getreue Rekonstruktion des Lappens und Voraussagen über Rutschgeschwindigkeiten von über $500 \mathrm{~m} / \mathrm{a}$ und Wasserführungen von nahezu $1 \times 10^{11}$ $\mathrm{m}^{3} / \mathrm{a}$ zu machen. Dies subglaziale Wasser bewirkte ein baumartiges Kanal-Muster, welches die statische Analyse der subglazialen Hydrologie richtig vorausgesagt hatte. In der Nähe des östlichen Eisrands bewirkte ein sehr viel breiterer einzelner Kanal gelegentlich eine subglaziale Dränage, und tributäre, durch Eis eingeschlossene Seen entließen ihr Wasser in Gletscherläufen. Basales Schmelzwasser bewirkte fast hydrostatische Wasserdruckwerte und sehr niedrige Widerstände des Tills an der Basis der Eisdecke. Der Wasserdruck sank nur in der Nähe des Eisrands, so daß normaler Druck bis zu bedeutenden Proportionen der totalen Eislast anstieg. So sind die bedingungen des Bettes sehr verschieden, je nachdem ob es sich in der Randzone oder der inneren Zone befindet. Obgleich die Beobachtung der subglazialen Ablagerungen die Endphase der Randzone spiegelt, könnten doch die Bedingungen im Innern der Eisdecke, die für die Geschichte und das Verhalten des Gletschers viel wichtiger sind, sehr verschieden sein. 


\section{INTRODUCTION}

The Puget lobe of the Cordilleran Ice Sheet formed the southwest-most extention of ice during the last glaciation of North America (Fig. 1). Beginning as coalescing mountain ice caps in British Columbia, the lobe advanced first as a tongue of ice along the Georgia Depression and then extended farther south along the trough of the Puget Lowland in western Washington state. At ice maximum, the lobe was about $100 \mathrm{~km}$ wide; its lateral extent was largely confined by the Olympic Mountains to the west and the Cascade Range to the east. In contrast, its southernmost limit reflected more the balance of ice-sheet accumulation and ablation than any significant topographic barriers.

Over a century of study has developed a picture of ice-sheet chronology, erosion, and deposition. Yet many of the basic questions of ice-sheet behavior, particularly how the landforms of the region have been shaped, are addressed only imperfectly by such studies. I have sought to approach some of these questions, particularly those pertaining to subglacial water flow and the properties of subglacial sediment, by using the rapidly increasing understanding of glacier physics. The results of similar efforts from other geographic regions also are relevant, because the underlying mechanical and material laws are universal.

For a number of reasons, the Puget lobe provides an exceptional opportunity to examine the connection between glacier physics and the geomorphic products of the glacier system. Most importantly, the Puget lobe forms a well-constrained system, with good age control, clearly recognized boundaries, and moderately definitive source area. The geomorphic products of glaciation are well-displayed across the Puget Lowland, despite the region's luxuriant vegetation cover. Rapid urbanization of this region has provided good access, widespread exposures, and relatively dense subsurface data. Finally, a number of ancillary studies of late Pleistocene environments in the region, particularly those reflecting climatic variation from local glaciers (Porter, 1977), vegetation (Barnosky et al., 1987), and global climate (Kutsbach, 1987), establish an independent environmental context and provide invaluable checks on the results of ice-sheet reconstruction and modeling.

The following discussion of the physics and the physical processes of the Puget lobe draws heavily on recent studies, not only those of the Puget lobe itself (e.g., Booth, 1986a,b; Brown et al., 1987; Thorson, 1989) but also those of other regions using compatible analyses (e.g., Boulton and Paul, 1976; Pierce, 1979; Shreve, 1985; Ridky and Bindschadler, 1990). In this region I have focused on the subglacial water system, because the movement of water at and within the glacier appears to have controlled the most significant aspects of the Puget lobe and its geomorphic effects. This significance is probably not unique to the Puget lobe; instead, it may be pervasive wherever large temperate glaciers sustained high discharges of both water and ice (Gustavson and Boothroyd, 1987).

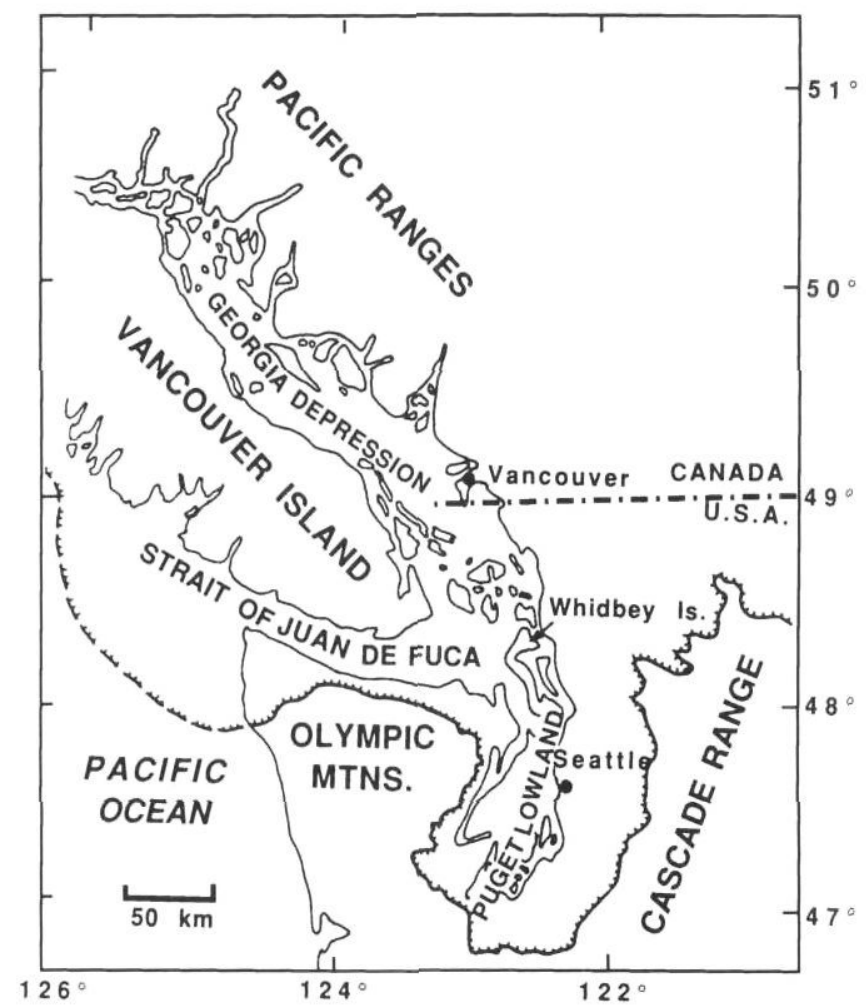

FIGURE 1. The Puget Lobe of the Cordilleran Ice Sheet, showing maximum extent (ca. $15 \mathrm{ka} \mathrm{BP}$ ).

Étendue maximale du lobe de Puget de l'Inlandsis de la Cordillère, vers $15 \mathrm{ka} B P$.

\section{REGIONAL SETTING}

\section{GEOGRAPHY}

The southwest part of the Cordilleran Ice Sheet occupied a distinctive geographic region. A broad topographic basin in British Columbia, the Georgia Depression and the Fraser Lowland, extends southward into Washington state. The depression splits at the northeast corner of the Olympic Peninsula. One branch extends west, between the Olympic Mountains and Vancouver Island, as the Strait of Juan de Fuca. The other branch continues south, forming the Puget Lowland between the Olympic Mountains and Cascade Range. Although low hills at about $46^{\circ} 45^{\prime}$ define the southern limit of ice advance in the Puget Lowland, the lowland province itself continues south for at least several hundred kilometers.

The southern Cordilleran Ice Sheet has expanded into the Puget Lowland during several glaciations during the Pleistocene (Crandell et al., 1958; Easterbrook et al., 1967). The most recent advance, the Vashon stade of the Fraser glaciation of Armstrong et al. (1965), provides the best picture of ice-sheet growth and decay. Ice caps on the mountains of Vancouver Island and the British Columbia mainland expanded and coalesced, gradually extending into the lowland valleys and the Georgia Depression (Clague, 1981). As the ice tongue moved into the Puget Lowland, it received no additional lateral input - mountain glaciers in the Olympics and Cascades had 


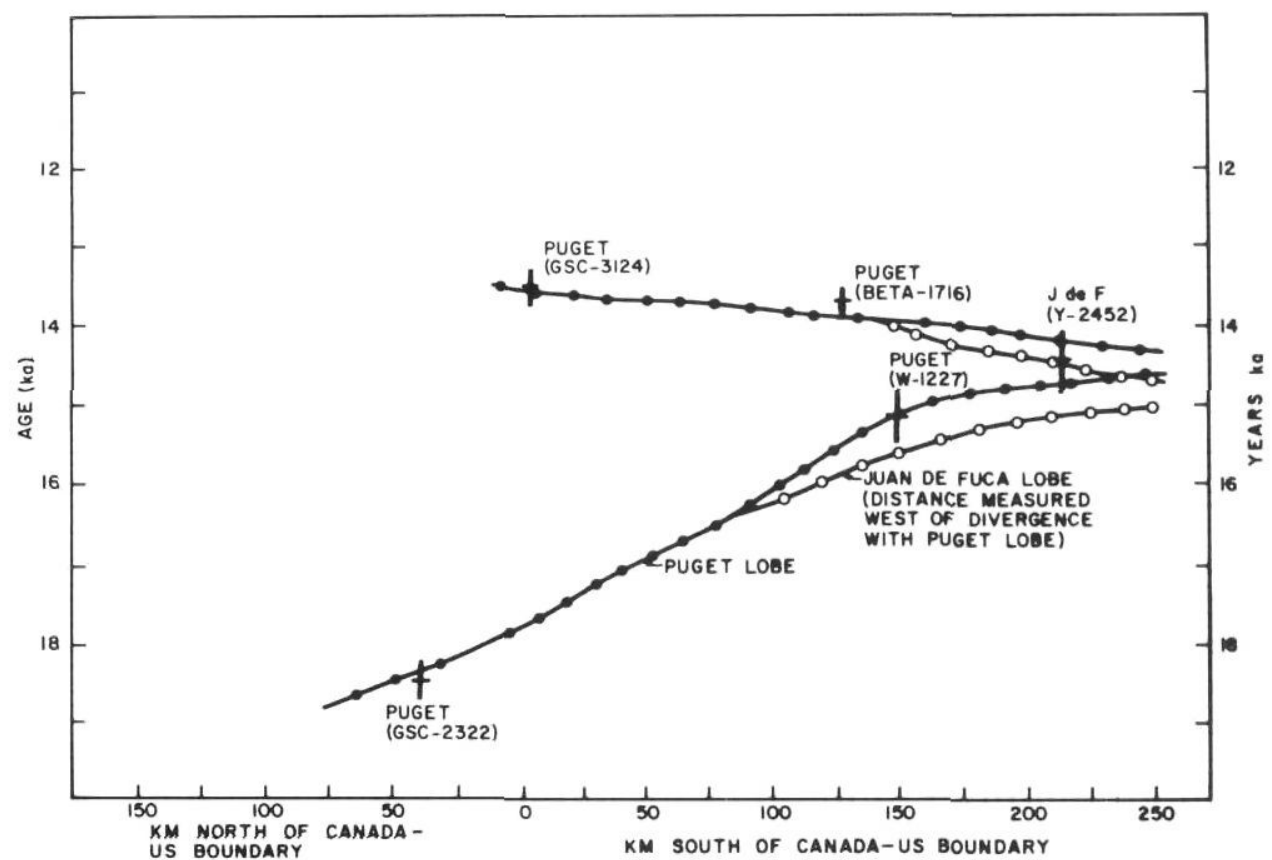

FIGURE 2. Advance and retreat of the Puget and Juan de Fuca lobes, with key limiting radiocarbon dates and standard errors (adapted from Booth, 1987).

Avancée et retrait des lobes de Puget et de Juan de Fuca ainsi que les principales dates au radiocarbone et leurs marges d'erreur (adapté de Booth, 1987). already retreated from their late Pleistocene maximum limits and probably did not contribute any additional ice to the Puget lobe (Porter, 1976; Booth, 1987).

\section{CHRONOLOGY}

During the Fraser Glaciation, the advancing and retreating Puget lobe was among the more rapid-moving of the North American ice sheets. Only a few thousand years span the advance of the lobe across the Canadian border, attainment of maximum southern position, and retreat back to the foothills of the British Columbia mountains. A movement of the terminus of over $200 \mathrm{~km}$ in each direction was therefore accomplished in this period, for an average velocity at the terminus of at least $100 \mathrm{~m} / \mathrm{a}$. Yet the geomorphic record in the Puget Lowland is primarily that of an ice sheet at maximum stage (see also Sugden, 1979), with relatively well-defined ice limits and iceflow patterns that are consistent with a sustained ice-maximum position (Thorson, 1980; Booth, 1984b). Thus the lobe undoubtedly maintained its maximum position for at least some fraction of its total history, with limiting radiocarbon dates (see below) permitting 500-1000 years of maximum or nearmaximum conditions. Advance and retreat rates were therefore even higher than their minimum, averaged value of $100 \mathrm{~m} / \mathrm{a}$.

Abundant radiocarbon dating constrains both the advance and the retreat chronology of the Puget lobe and the neighboring Juan de Fuca lobe (Fig. 2). The ice sheet entered the Fraser Lowland some time after $18.3 \pm 0.17 \mathrm{ka}$ (GSC-2322; Armstrong and Clague, 1977, Fig. 2). The advance of the Puget lobe is further constrained in the Seattle area, $160 \mathrm{~km}$ south of the International Boundary, by a pre-glacial age of $15.0 \pm 0.4$ ka (W-1227; Mullineaux et al., 1965).

Final advance to the ice-maximum position and subsequent retreat are also detailed for both lobes. The Juan de Fuca lobe has one dated locality near its terminus, a post-retreat date of
$14.46 \pm 0.20 \mathrm{ka}(\mathrm{Y}-2452$; Heusser, 1973) $50 \mathrm{~km}$ upglacier of its ice-maximum limit. The Puget lobe advanced an additional $100 \mathrm{~km}$ south of Seattle and then retreated a like amount between $15.0 \mathrm{ka}$ (see above) and $13.65 \pm 0.55 \mathrm{ka}$ (L-346a; Rigg and Gould, 1957). Yet nearly equivalent dates of $13.60 \pm 0.15 \mathrm{ka}$ and $13.65 \pm 0.35 \mathrm{ka}$ are also reported from shells on Whidbey Island, an additional 30 to $50 \mathrm{~km}$ north of Seattle (BETA-1716 and BETA-1319; D. P. Dethier et al., written communication, 1986). Grounded ice of both the Puget and Juan de Fuca lobes therefore must have retreated at least this far upglacier by that time. Required minimum rates of terminal advance and retreat are about $200 \mathrm{~m} / \mathrm{a}$ during this period; allowing for slower advance rates (Weertman, 1964) and sufficient time to achieve equilibrium at ice-maximum position, actual retreat rates were probably closer to $500 \mathrm{~m} / \mathrm{a}$.

The character of the final retreat and decay of the combined Puget and Juan de Fuca lobes is suggested by both radiocarbon dates and the types of recessional deposits. In contrast to the southern Puget Lowland, where dead-ice topography is relatively rare and active ice margins systematically diverted glacial meltwater at the ice margin (Thorson, 1980; Booth, $1987,1990)$, the northern lowland and eastern Strait of Juan de Fuca display either irregular recessional deposits (Anderson, 1968; Chrzastowski, 1980), glaciomarine drift (Easterbrook, 1963; Pessl et al., 1987), or no deposits at all. This irregularity of deposition is matched by a broad suite of dates in this region, spanning in time from $13.65 \pm 0.35 \mathrm{ka}$ (BETA-1319) to $11.30 \pm 0.07$ ka (USGS-124; Dethier et al., written communication, 1986) and in space from Whidbey Island north to the International Boundary. In this region, the ice probably retreated primarily by calving, with local backwasting and stagnation (Pessl et al., 1987). Marine sedimentation would have continued until isostatic rebound finally lifted much of the area above sea level (Thorson, 1989). 


\section{RECONSTRUCTION OF THE PUGET LOBE}

Determining the physical behavior of an ice sheet first requires some knowledge of its physical dimensions. The flux of both ice and water must be estimated as well, because the passage of these agents over the glacier bed is what yields geomorphic changes. Unfortunately, most glacier systems are ill-suited to such a reconstruction. If applied to an existing glacier, the necessary parameters are easily measured but their effects on the glacier bed are obscured. Pleistocene ice sheets suffer from the inverse problem - typically, the record of their passage is grossly incomplete or their mass-balance regime is completely unknown. The Puget lobe does not avoid completely these shortcomings of other vanished ice sheets, but sufficient data are available and constrained by independent checks that reconstruction is both feasible and instructive. The discussion of method and results that follow are summarized from Booth (1986a), which includes a more extensive review of techniques, data sources, errors, and independent verifications.

\section{METHODS}

This reconstruction is based first on the compilation of available geologic data on the physical extent of the ice sheet (Fig. 3) and second on the calculation of an equilibrium mass balance for the Puget lobe itself. The southern boundary of the ice sheet, along the boundary of the Puget lobe, is rather wellconstrained; the southwestern boundary was formed by the tidewater part of the Juan de Fuca lobe and so is far less certain. Ice-flow direction indicators discriminate the source area of the two lobes in southern and central British Columbia; the altitude of marginal ice limits and nunataks provide most of the data for ice-surface contours. This compilation relies heavily on Thorson (1980) in the south and Wilson et al. (1958) in the north. I have sought to reconcile these and other subsequent reconstructions using several basic assumptions: ice-surface contours lie perpendicular to flow indicators, flow lines do not converge or diverge without commensurate changes in ice thickness or net mass balance, and longitudinal stress gradients (i.e. the downglacier change in the depth-slope product) are low at the scale of the reconstruction.

The mass balance of an ice sheet during the Pleistocene cannot be known with certainty, but analogy with existing glaciers provides a reasonable working estimate. In the Pacific Northwest, long-term study of a number of modern maritime glaciers yields a local mass-balance relationship (Meier et al., 1971; Porter et al., 1983), expressing net accumulation or ablation as a function of elevation above or below the equilibrium line altitude, or ELA (Fig. 4). The total ablation provides a measure of the water production that discharges through the glacier, irrespective of whether that melting is compensated by snow accumulation or not. This relationship is compiled from high-quality data from two Norwegian maritime glaciers (IAHS, 1977).

\section{RESULTS}

With a reconstructed ice sheet and a relationship between relative altitude and mass balance, an ELA can be determined

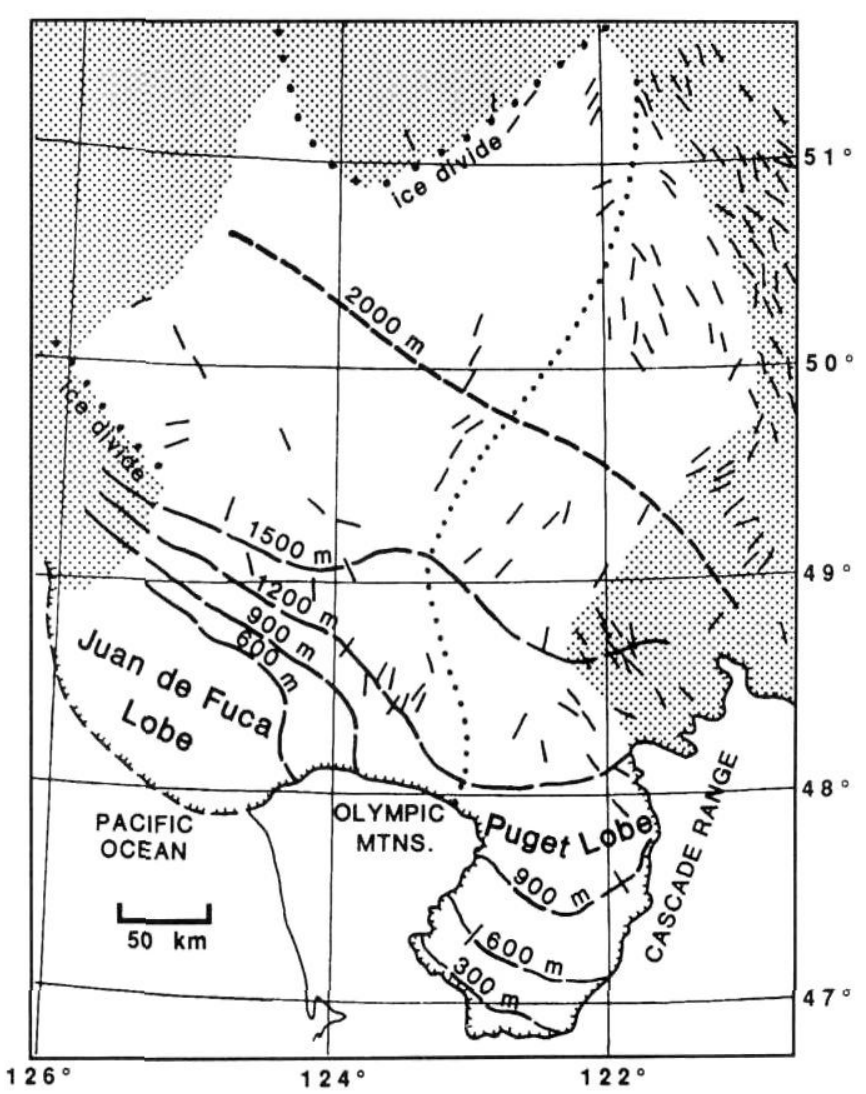

FIGURE 3. Reconstruction of the Puget and Juan de Fuca lobes of the Cordilleran Ice Sheet at maximum stage. Short lines show orientation of representative striations and other glacial lineations; hatchured line shows maximum extent of ice. Heavy lines are contours of icesurface altitudes above modern sea level, uncorrected for glacial-age sea level lowering or isostatic depression. Unshaded ice-covered area included all ice of the Puget and Juan de Fuca lobes, with an inferred separation between the lobes indicated by the dotted line (adapted from Booth, 1986a).

Reconstitution des lobes de Juan de Fuca et Puget de l'Inlandsis de la Cordillère à l'optimum glaciaire. Les petits traits donnent l'orientation des stries et autres marques glaciaires représentatives: la ligne à barbules montre l'étendue maximale des glaces. Les lignes discontinues montrent l'altitude des surfaces glaciaires au-dessus du niveau actuel de la mer, non corrigée en fonction de l'abaissement isostatique de l'époque glaciaire. La région glaciaire non tramée comprend l'ensemble des deux lobes; une séparation hypothétique entre les deux lobes est indiquée par le pointillé (à partir de Booth, 1986 a).

by trial and error that brings the lobe into balance. Conversely, if the ELA is known independently, the condition of net growth or decay can be easily calculated. In either case, the flux of both ice and water can be established as a function of position downglacier.

Using these procedures, the Puget lobe is calculated to be in balance with an ELA between 1200 and $1250 \mathrm{~m}$. Table I shows the resulting values of the ice and water fluxes for an ELA between these two levels. The contribution to ice velocity from internal ice deformation can be calculated (Paterson, 1981) and accounts for less than 2 percent of the total flux. Thus basal sliding must account for virtually all of the predicted motion, which is several hundred meters per year over nearly 


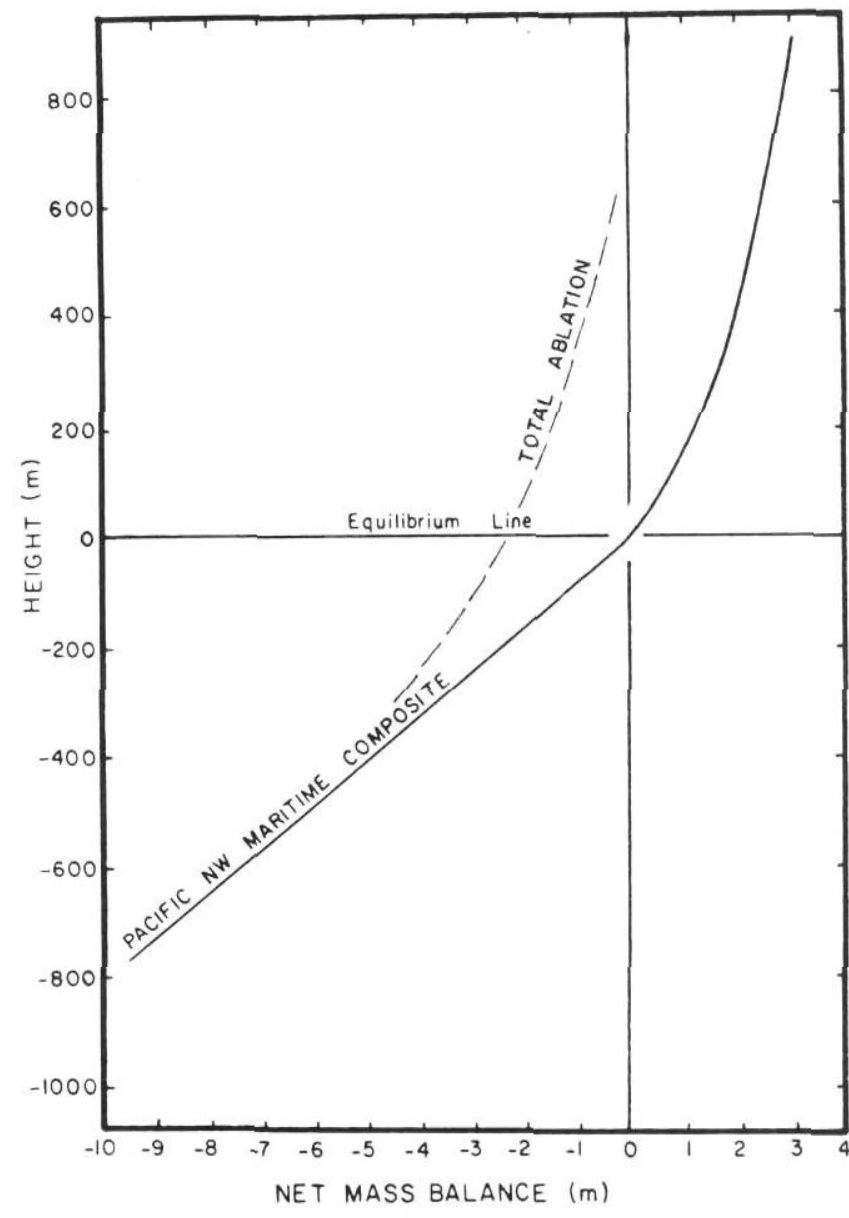

FIGURE 4. Height-mass balance relationships for modern maritime glaciers. Height is referenced to the equilibrium-line altitude; specific balance is in cubic meters of equivalent water volume per square meter of ice surface per year (adapted from Booth, 1986a, with original data from Meier et al., 1971, and IAHS, 1977).

Relations entre la hauteur et le bilan de masse pour des glaciers maritimes modernes. La hauteur est en fonction de l'altitude de la ligne d'équilibre; le bilan spécifique est en mètres cubes de volume d'eau équivalent par mètre carré de surface de glace par année (à partir de Booth, 1986a et des données originales de Meier et al., 1971 et IAHS, 1977).

TABLE I

Ice and water discharge through transverse sections of the Puget Lobe, ELA $=1225 \mathrm{~m}$ (adapted from Booth, 1986a)

\begin{tabular}{ccccc}
\hline $\begin{array}{c}\text { Contour } \\
\text { Interval } \\
(\mathrm{m})\end{array}$ & $\begin{array}{c}\text { Cross- } \\
\text { Sectional } \\
\text { Area } \\
\left(10^{8} \mathrm{~m}\right)\end{array}$ & $\begin{array}{c}\text { Water } \\
\text { Discharge } \\
\left(10^{10} \mathrm{~m}^{3} / \mathrm{a}\right)\end{array}$ & $\begin{array}{c}\text { Ice } \\
\text { Discharge } \\
\left(10^{10} \mathrm{~m}^{3} / \mathrm{a}\right)\end{array}$ & $\begin{array}{c}\text { Ice } \\
\text { Velocity } \\
(\mathrm{m} / \mathrm{a})\end{array}$ \\
\hline 2000 & 1.1 & 0.0 & 4.8 & 430 \\
1500 & 1.2 & 0.4 & 7.0 & 580 \\
1200 & 1.2 & 1.4 & 7.9 & 660 \\
900 & 0.9 & 3.5 & 6.4 & 540 \\
600 & 0.7 & 6.1 & 3.8 & 470 \\
300 & 0.4 & 8.6 & 1.2 & 310 \\
Terminus & 0 & 9.7 & 0 & 0 \\
\end{tabular}

the entire source and ablation areas of the lobe. The ice flux peaks at the ELA, in contrast to the monotonic increase in water flow downglacier (Fig. 5).

Nearly every element of this reconstruction is constrained by independent data; the net result, that of basal sliding of hundreds of meters per year, is unaffected by the uncertainties inherent in such an analysis. The mass-balance relationships are least verifiable, but the consequences of reduced accumulation-area snowfall or terminal ablation can be evaluated (Booth, 1986a). In both cases, any significant change in the mass-balance relationship raises or lowers the location of the ELA to geologically implausible levels; namely, moving the ELA onto areas of the lobe where flow lines either converge or diverge strongly.

\section{ICE-SHEET RECONSTRUCTION AND GLACIAL PROCESSES}

The effects of glaciation depend on certain key elements of the ice-sheet reconstruction. From lobe dimensions, the basal shear stress of the ice is readily calculated and ranges between 40-50 kPa (Booth, 1986a; Brown et al., 1987). Despite this shear stress, low by the standards of modern valley glaciers but apparently quite typical of ice streams and Pleistocene ice lobes (Blankenship et al., 1987; Mathews, 1974; Paterson, 1981), sliding velocities were many hundreds of meters per year. Ablation generated much meltwater, which approached and finally exceeded the flux of ice downglacier in the ablation zone. The system thus described is one of rapid mass transport under a rather low driving stress, traversing a bed of mainly unconsolidated sediment.

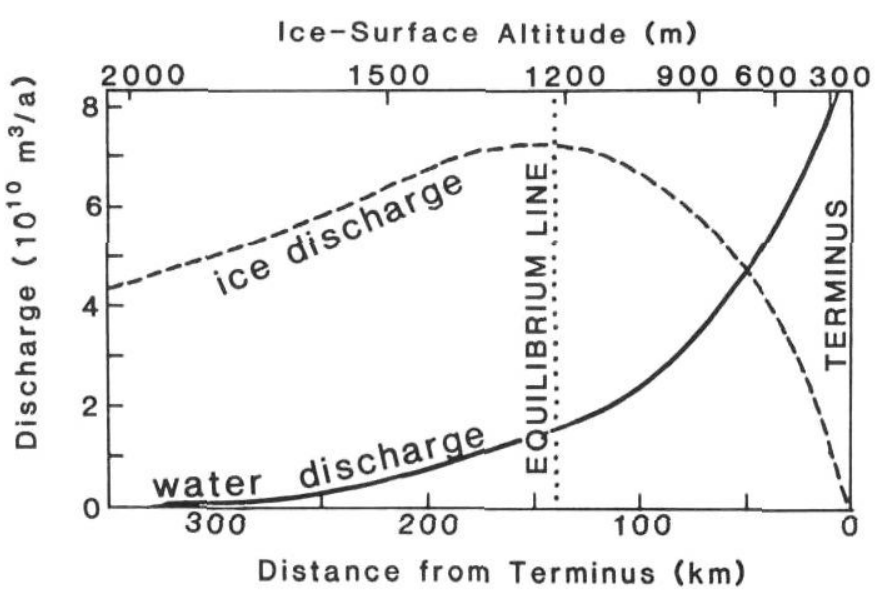

FIGURE 5. Variation of ice and water fluxes along the length of the Puget lobe, using an ELA of $1225 \mathrm{~m}$.

Variations des débits de glace et d'eau tout au long du lobe de Puget, selon une ligne d'équilibre à 1225 m d'altitude. 


\section{THE MOVEMENT OF SUBGLACIAL WATER}

Theory

Water flow through a glacier can be described by the same mathematical formulations developed for groundwater. Water moves from areas of high total potential, or total head, to areas of low total head. Flow is down the gradient of the potential field, analogous to the flow of surface water over the topography of a hillslope (Shreve, 1972; Rothlisberger, 1972).

Total head at a point has two significant static components: the elevation head, measured as the height of a point in the water above a chosen datum; and the pressure head, which for a steady-state water-filled tunnel is nearly equal to the overburden pressure due to the overlying ice (Shreve, 1972).

The total head $(H)$ is expressed in units of length and is the sum of the elevation head $(\mathrm{z})$ and the pressure head. Because:

$$
p_{i}=p_{i} g h,
$$

the total head is:

$$
H=z+\left(\frac{\rho_{\mathrm{i}}}{\rho_{\mathrm{w}}}\right) h
$$

where $p_{i}=$ the ice overburden pressure,

$$
\begin{aligned}
\rho_{\mathrm{w}} & =\text { water density, } \\
\rho_{\mathrm{i}} & =\text { ice density, } \\
\mathrm{g} & =\text { gravitational acceleration, and } \\
\mathrm{h} & =\text { the overlying thickness of ice. }
\end{aligned}
$$

Because $z+h$ is constant within any vertical column in the ice and $\rho_{i}<\rho_{w}$, total head will be lowest at the bed of the glacier (where $\mathrm{z}=\mathrm{Z}_{\mathrm{b}}$ ), and thus subglacial flow is favored over englacial flow (Shreve, 1972).

The gross pattern of water flow beneath the glacier is readily predicted from equation (1). Differentiation of that equation yields:

$$
\frac{\partial \mathrm{H}}{\partial \mathrm{x}}=\frac{\partial \mathrm{z}_{\mathrm{b}}}{\partial \mathrm{x}}+\left(\frac{\rho_{\mathrm{i}}}{\rho_{\mathrm{w}}}\right) \times \frac{\partial\left(\mathrm{z}_{\mathrm{s}}-\mathrm{z}_{\mathrm{b}}\right)}{\partial \mathrm{x}}
$$

where $\mathrm{x}=$ distance downglacier, and

$$
z_{s}=\text { the ice-surface elevation, } z_{b}+h \text {. }
$$

If two points on the glacier bed have the same total head,

$$
\frac{\partial H}{\partial x}=0
$$

and so:

$$
\frac{\partial z_{s}}{\partial x}=-0.09\left(\frac{\partial z_{b}}{\partial x}\right)
$$

So long as the bed does not slope upglacier more steeply than eleven times the downglacier ice slope, total head will decrease downglacier and water will follow the ice slope direction, flowing up or down the bed topography with only minor deflection (Shreve, 1972, 1985).

\section{Reconstruction}

Using this static analysis of subgiacial water flow, the potential field at the bed of an ice sheet can be developed. The approach used here is conceptually identical to that followed by Shreve (1985) for a portion of the Laurentide Ice Sheet in the state of Maine. It requires two reconstructed elements: the topography of the bed and the topography of the ice-sheet surface. The reconstructions are detailed for a part of the eastern Puget lobe (Fig. 6), using digitized topography from U.S. Geological Survey 1:24,000 and 1:62,500 topographic maps (Fig. 7) and a more detailed version of the ice-sheet reconstruction shown in Figure 3 (Fig. 8). No correction is made for postglacial modification of the bed topography, undulations in the ice surface from bed irregularities (Robin, 1967), dynamic pressures imposed by the flowing ice, or isostatic rebound following deglaciation, as the overall results are insensitive to these complications (Booth, 1984b).

The subglacial potential field is calculated with these data and equation (1). The resulting equipotentials, or contours of equal total head, define the conceptual "topography" down

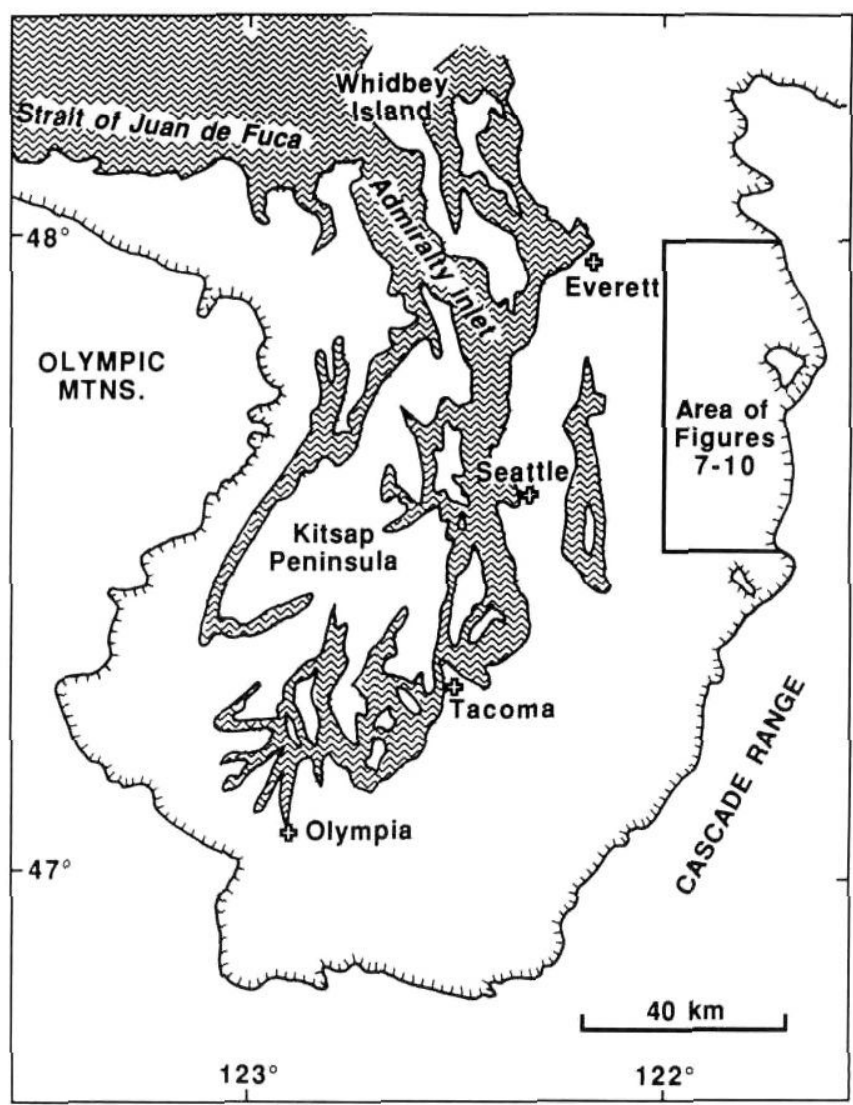

FIGURE 6. Index map of the Puget lobe, showing the area of reconstructed subglacial hydraulic equipotentials along the eastern margin in the Skykomish-Snoqualmie region (Figs. 7-10).

Carte index du lobe de Puget, montrant la région où l'on a fait la reconstitution des zones des équipotentiels hydrauliques sousglaciaires le long de la marge orientale, dans la région de SkykomishSnoqualmie (fig. 7 à 10). 


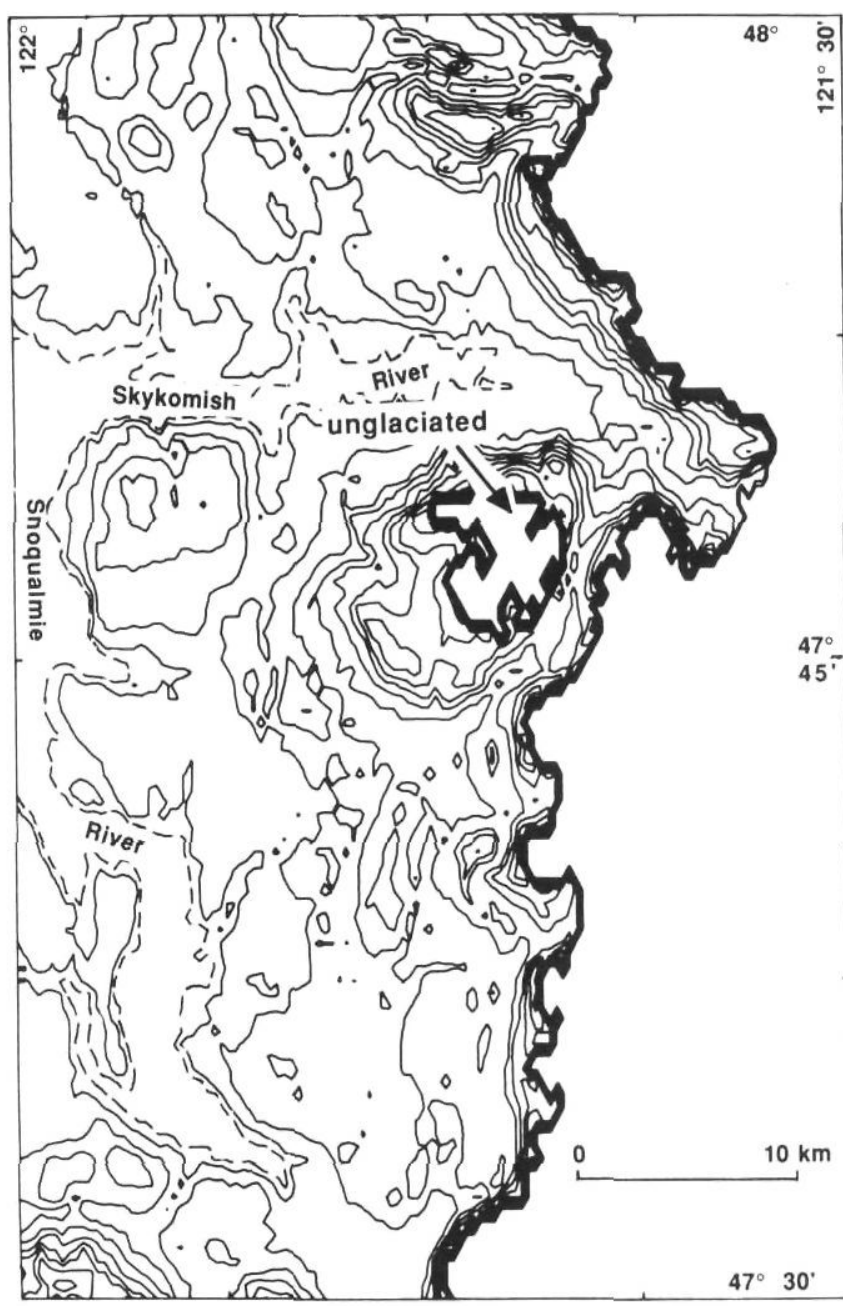

FIGURE 7. Ground topography of the Skykomish-Snoqualmie region outlined in Figure 6. Contour interval $100 \mathrm{~m}$ (dashed contour $=50 \mathrm{~m}$ ), digitized from USGS topographic maps. Dark line at eastern border is the Vashon-age ice limit, approximated at the mouth of each alpine valley.

Topographie de la région de Skykomish-Snoqualmie (voir fig. 6). L'équidistance des courbes est de $100 \mathrm{~m}$ (courbes interrompues = $50 \mathrm{~m}$ ), digitalisées à partir des cartes topographiques du USGS. Le trait gras à la marge orientale représente la limite glaciaire de Vashon, approximative à l'embouchure des vallées alpines.

which subglacial water would flow (Fig. 9). The channelized features are highlighted in Figure 10 by following all lows in the potential surface from the upglacier boundaries of the map. The interconnection of these valleys, not always obvious in the modern topography, become apparent when viewed in their proper subglacial context.

The potential field defines two distinct categories of subglacial channels. The first category of channels forms the crudely dendritic network across the region in Figure 10. Water flow follows routes of monotonically decreasing gradient, with divergent flow paths drawn where the resolution of the reconstruction is inadequate to specify a singular route. The net flow is to the south and west, reflecting the overall control of the icesurface slope in the downglacier direction. Variations in that overall pattern, however, are imposed by the bed topography.

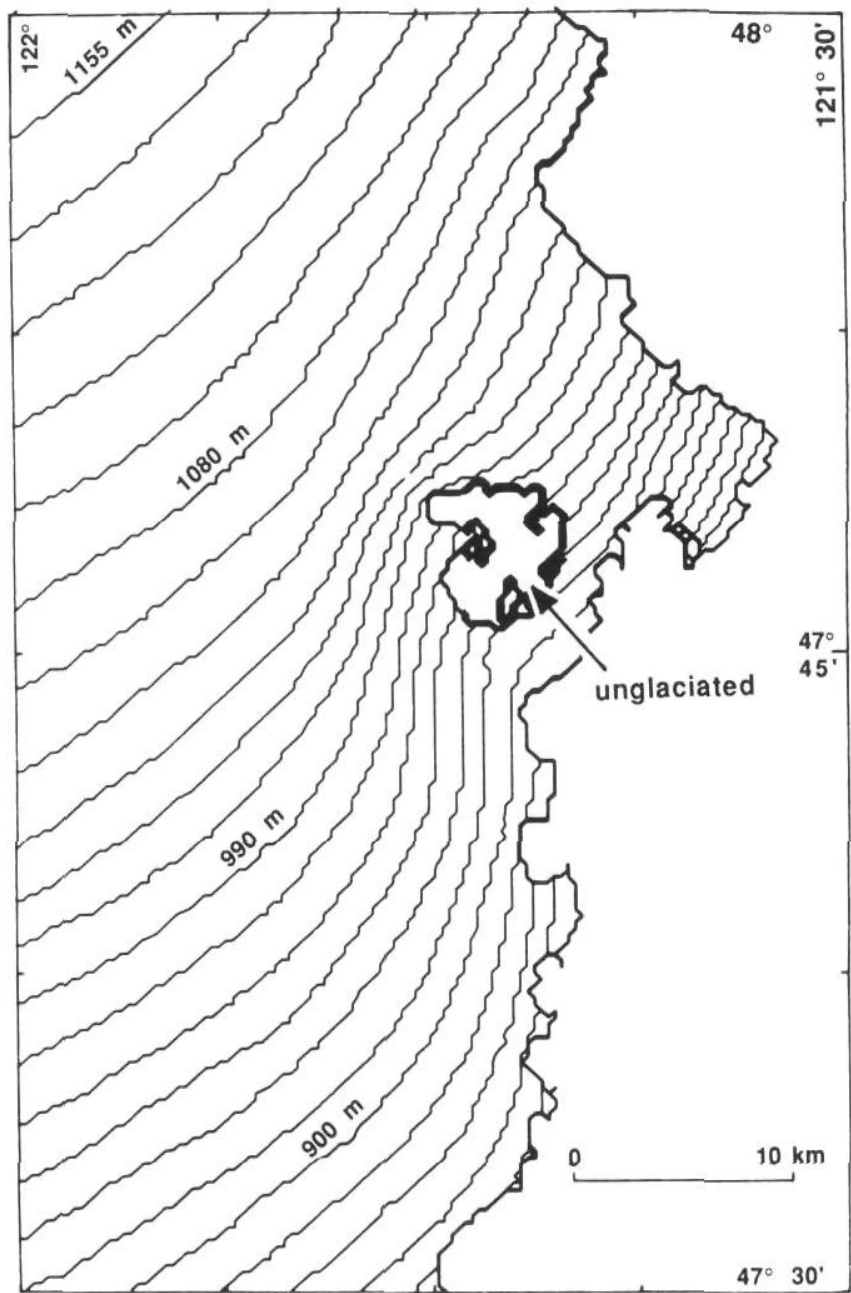

FIGURE 8. Ice-sheet topography of the Puget lobe at maximum stage in the Skykomish-Snoqualmie region (Fig. 6). Contour interval is $15 \mathrm{~m}$.

Topographie du lobe de Puget à son optimum dans la région de Skykomish-Snoqualmie (fig. 6). L'équidistance est de $15 \mathrm{~m}$.

In turn, the channelizing of subglacial flow could have enhanced this topography by fluvial erosion.

The second category of channel follows a single submarginal valley near the eastern (lateral) boundary of the reconstructed ice sheet. This channel does not, however, experience monotonically decreasing hydraulic gradients. instead, local saddles in the potential field block the flow. As with subaerial spillways, water would be impounded behind them; here, that water would have formed subglacial and submarginal lakes in the alpine valleys immediately upglacier of each saddle (Booth, 1986b).

Yet unlike subaerial spillways, the control of lake elevation depended not only on saddle elevation but also on ice pressure. As the lakes filled from subglacial influx and drainage from Cascade Range rivers, the elevation of the lake would have exceeded the potential of the spillway and subglacial drainage would begin. Rapid melting of a tunnel to accommodate this drainage would remove the component of the hydraulic poten- 


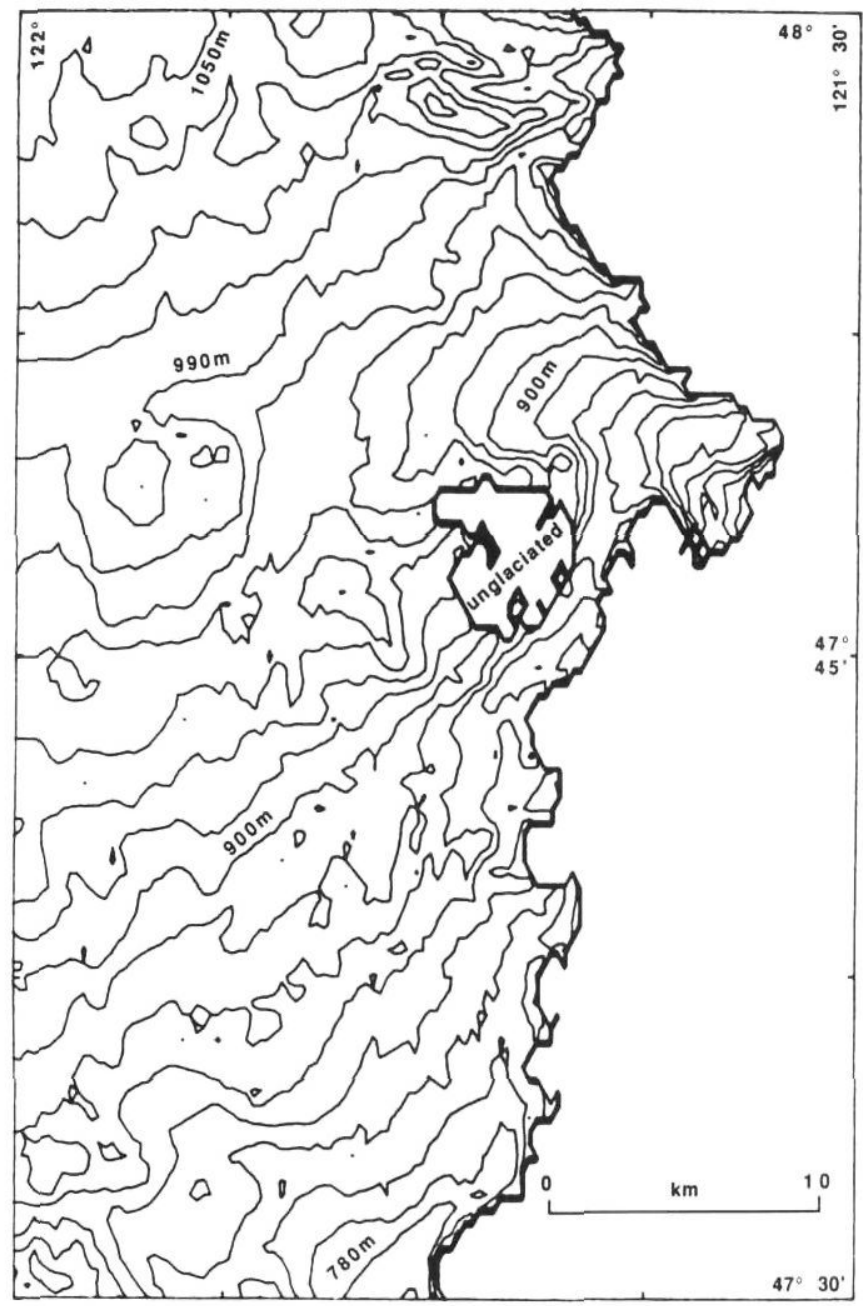

FIGURE 9. Calculated subglacial hydraulic equipotentials in the Skykomish-Snoqualmie region (Fig. 6). Equipotentials are defined from equation (1), such that water of a given potential will stand at that altitude in a borehole or adjacent lake. Contour interval is $15 \mathrm{~m}$; alpine valleys labeled along the eastern ice margin (adapted from Booth, 1986b).

Equipotentiels hydrauliques sous-glaciaires calculés dans la région de Skykomish-Snoqualmie. Les équipotentiels sont définis à partir de l'équation (1) de telle façon que l'eau d'un potentiel donné se maintiendra au même niveau dans un trou de sondage ou un lac adjacent. L'équidistance est de $15 \mathrm{~m}$ (adapté de Booth, 1986b).

tial at the spillway due to the ice overburden (Nye, 1976). This radical reduction in potential would precipitate catastrophic discharge of the marginal lake as a jokulhlaup, observed on numerous modern ice-dammed lakes (Stone, 1963; Post and Mayo, 1971). The submarginal flow path of Figure 10 was therefore episodic in nature.

The ice-marginal lakes also lie in sequence - a discharge of one would drain, via the submarginal channel and diversion by the next subglacial spillway downglacier, into the next lake to the south. Drainage of the largest lake (that occupying the modern Skykomish River valley, with an estimated volume of $120 \mathrm{~km}^{3}$ ) probably would have triggered all others downglacier, because it contained over five times the combined volume of its downstream neighbors. Its refilling time, based on modern

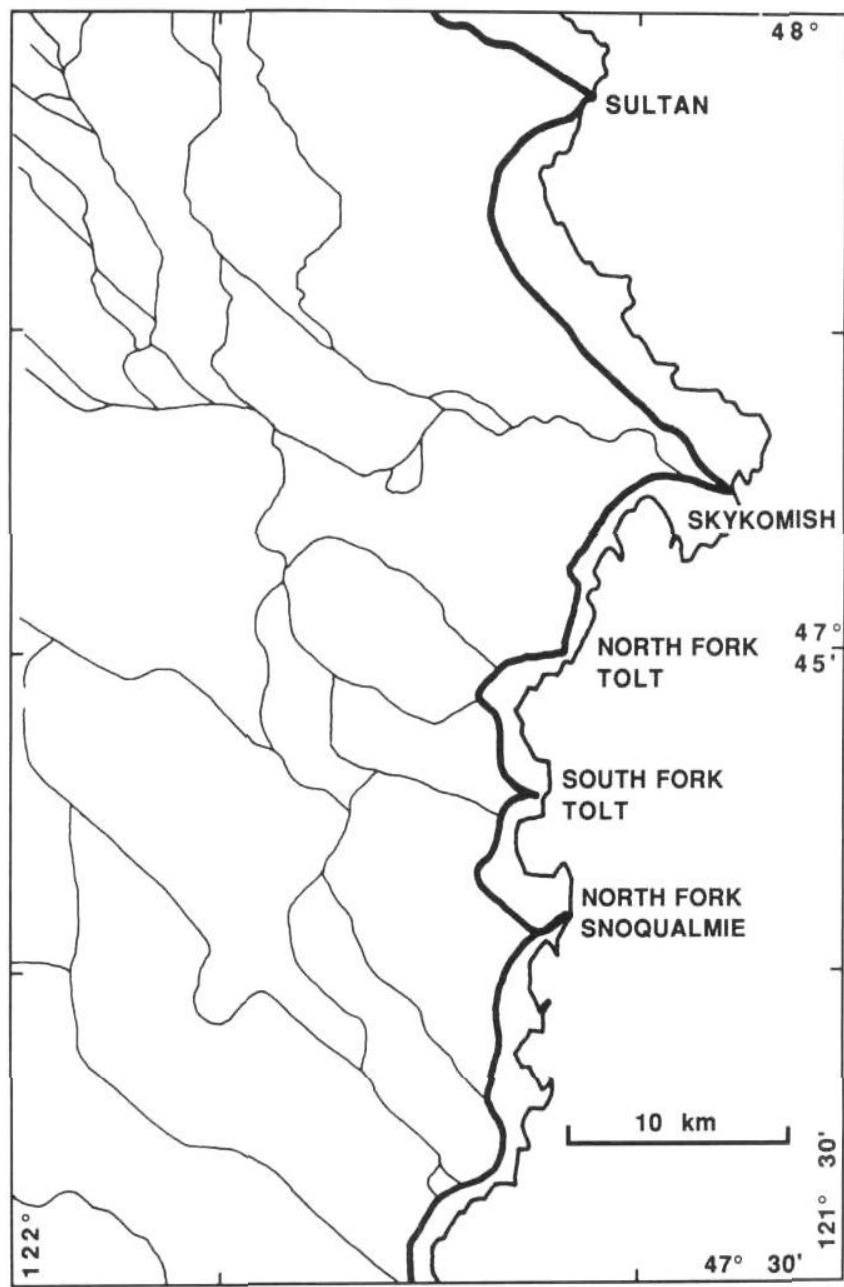

FIGURE 10. Channelized features in the equipotential surface of Figure 9. The thin lines trace a dendritic network of monotonically decreasing hydraulic potential; the thick line marks a single marginal channel where flow was diverted by saddles into adjacent ice-free valleys (named on map), forming ice-marginal lakes that drained episodically.

Chenaux établis à partir de la surface des équipotentiels de la figure 9. Les traits fins identifient un réseau dendritique au potentiel hydraulique décroissant de façon uniforme; le trait gras montre un chenal isolé où l'écoulement était dérivé vers les vallées déglacées adjacentes par des cols formant ainsi des lacs de marge glaciaire qui se vidangeaient épisodiquement.

precipitation rates (U.S. Geological Survey, 1983; see Porter, 1977 , for a discussion of their applicability) would have been only a few decades (Booth, 1984b, Table 3.1). Thus multiple discharges along the Cascade margin probably were inevitable during the occupation of the Puget lobe.

\section{LANDFORMS OF SUBGLACIAL WATER FLOW}

Across the Puget Lowland, the effects of channelized subglacial water are evident. They are particularly prominent towards the lateral margins of the ice sheet's ablation zone. Here, the cumulative effect of upglacier melting increased the total available water, and the convexity of the ice surface drove water into this region, away from the center of the lowland. Erosional features have persisted best in the bedrock uplands, 
above the level of recessional lakes and outwash deposits that now fill most of the lower valleys (Bretz, 1913; Thorson, 1980; Booth, 1990).

The erosional channels share a number of characteristics reported elsewhere in regions covered by Pleistocene ice sheets (e.g., Mannerfelt, 1949; Sissons, 1963; Clapperton, 1968; Ehlers; Sharpe and Shaw, 1989). They are sinuous to linear valleys, commonly occupied now by bogs or underfit streams, with steep sidewalls of 10 s to over 100 meters high. Small-scale polishing and smoothed sculpted "p-forms" (Dahl, 1965; Sharpe and Shaw, 1989) are sporadically exposed along the bedrock walls. Their modern drainage areas are typically trivial and their gradients are very low, precluding significant postglacial incision. Conversely, their orientations are commonly oblique to independent indicators of ice flow, particularly striae on adjacent uplands, limiting the amount of ice scour possible during their formation.

The episodic, submarginal channel near the eastern ice margin is a unique display of the power of subglacial water processes. The present valley is incised over $150 \mathrm{~m}$ into the glaciated upland surface to the west (towards the center of the ice lobe) and lies at the base of a 400-meter escarpment to the east (towards the ice margin; Fig. 11). Although early reconstruction of the Puget lobe (Mackin, 1941) recognized that an immense flux of meltwater must have filled this channel, only its relatively brief function as a subaerial, ice-marginal channel during the ice recession had been understood. As a result, the channel's long-term occupation by subglacial flow and episodic, catastrophic jokulhlaups (Booth, 1984a,b, 1990) remained uninvestigated until the present reconstruction of subglacial water flow (Fig. 9).

The magnitude of discharges along this channel can be estimated from empirical relationships between lake volume and jokulhlaup discharge. The formula of Clague and Mathews (1973), with modification by Begét (1986) -

$$
\mathrm{Q}_{\max }=0.0065 \mathrm{~V}^{0.69}
$$

where $\mathrm{Q}_{\max }=$ maximum jokulhlaup discharge in $\mathrm{m} / \mathrm{sec}$, and

$$
\mathrm{V}^{\mathrm{max}}=\text { initial lake volume in } \mathrm{m}^{3}-
$$

predicts maximum discharges from the impounded icemarginal lakes (with a release volume of $10^{11} \mathrm{~m}^{3}$ ) of order $10^{5} \mathrm{~m}^{3} / \mathrm{sec}$. By comparison, this is one to two orders of magnitude less than predictions of Lake Missoula floods (Baker, 1973; Clarke et al., 1984; Begét, 1986) and of inferred sheet floods beneath the Laurentide Ice Sheet (Shaw and Gilbert, 1990), five to ten times greater than reported from computed paleodischarges in the Rocky Mountain Trench (Clague, 1975), and one to two orders of magnitude greater than reported from modern Alaskan ice-dammed lakes (Stone, 1963). Deposits associated with these Puget-lobe jokulhlaups would be largely covered by later recessional-outwash deposits that occupied the same channel. However, record of at least one and probably two discrete episodes is preserved and exposed by layers of 1- to 3-m boulders, located about $2 \mathrm{~km}$ downstream of the controlling spillway for the largest lake in the marginal system, Glacial Lake Skykomish (Fig. 12).

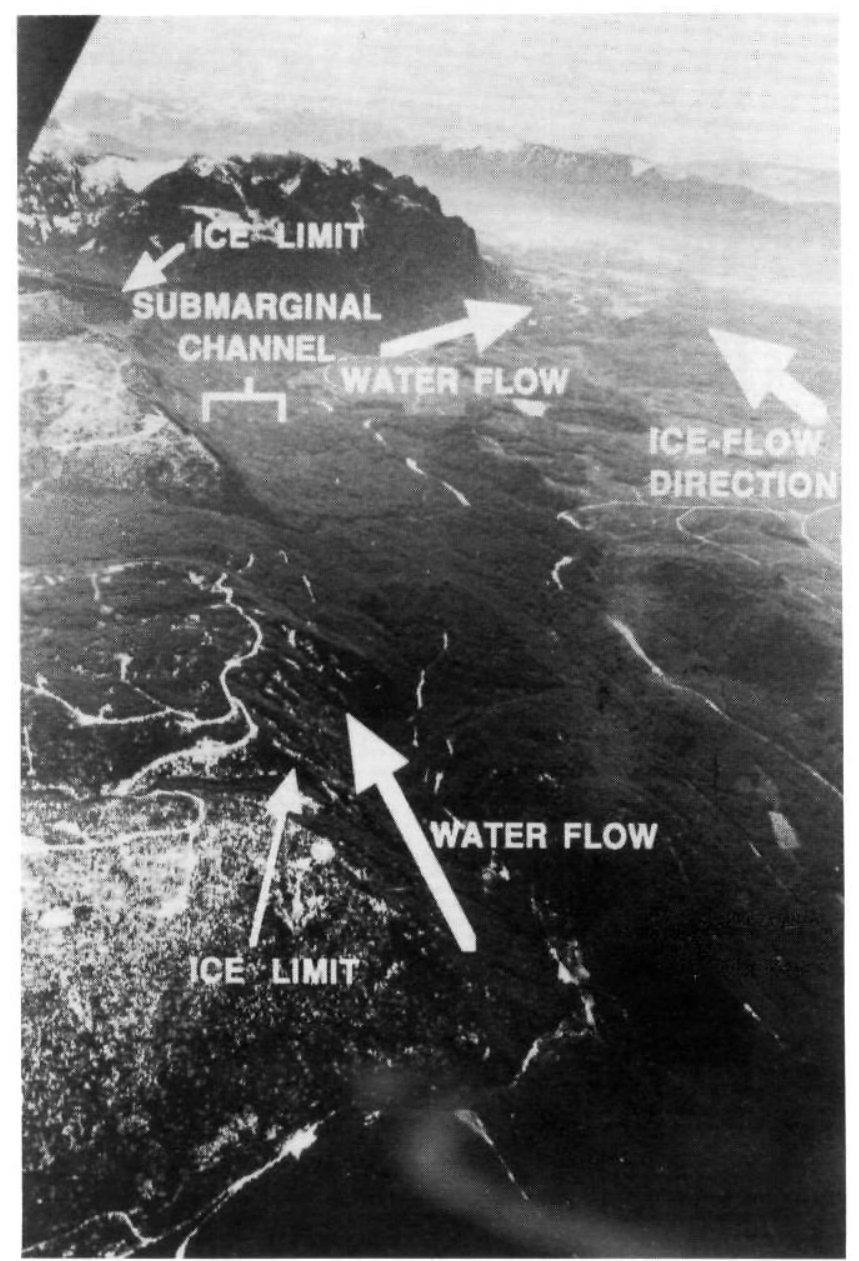

FIGURE 11. Aerial view of the submarginal channel of the eastern Puget lobe, looking south. The left (eastern) escarpment is about $400 \mathrm{~m}$ high, and the valley of the submarginal flow is at most about $2 \mathrm{~km}$ wide. View covers the southeast corner of Figures 7-10, with the valley of the North Fork Snoqualmie River in the lower left corner.

Vue aérienne vers le sud du chenal de la marge orientale du lobe de Puget. L'escarpement à gauche a une puissance de $400 \mathrm{~m}$ et la vallée du chenal mesure au plus $2 \mathrm{~km}$ de large. La photo couvre le coin sudest des figures 7 à 10, avec dans le coin inférieur gauche, la vallée de North Fork Snoqualmie River.

\section{WATER PRESSURE AND THE PROPERTIES OF SUBGLACIAL SEDIMENT}

Basal drag imposed by sliding

The dual conditions of high sliding velocities and low basal shear stresses, reconstructed for most of the Puget lobe's length, constrain any hypothesis on the state of the ice-bed interface. Calculations of the drag imposed by a rigid bed of till (Brown et al., 1987) show that even with generous assumptions of ice viscosity, cavitation, and interference between the projection of till clasts extending up into the ice, the drag on ice sliding at $500 \mathrm{~m} / \mathrm{a}$ is about one order of magnitude greater than the driving shear stress of the ice. Thus bed deformation or ice-bed separation, both implying pervasively high porewater pressures at the glacier bed, must have occurred. 


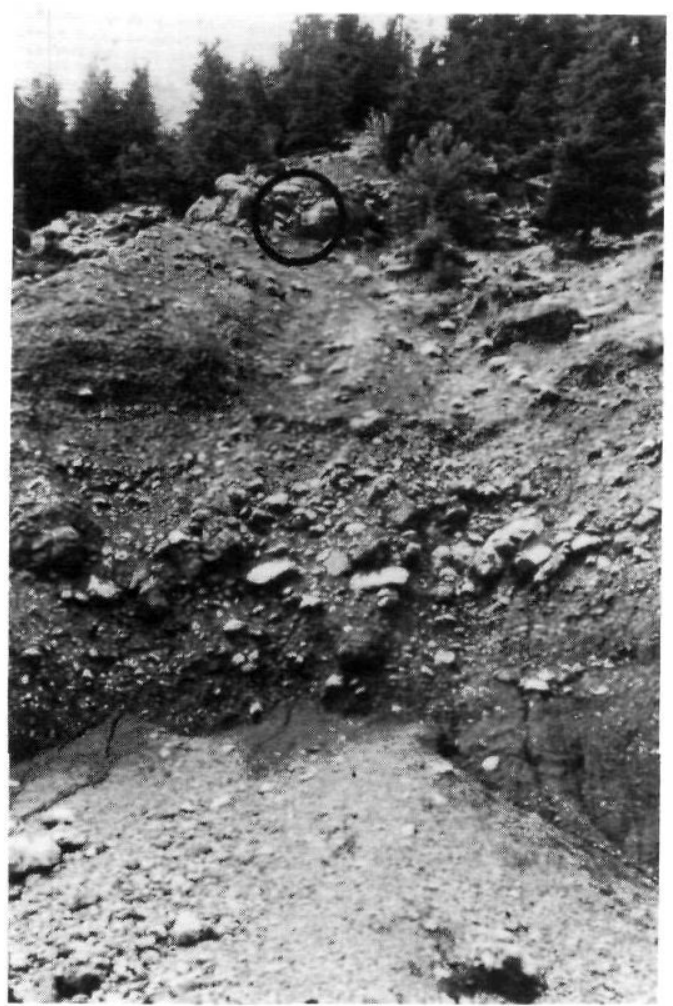

FIGURE 12. Gravel deposits of one or more jokulhlaups, deposited downstream of Glacial Lake Skykomish above the valley of the North Fork Tolt River (Booth, 1986b). Largest boulders are about $3 \mathrm{~m}$ in diameter; note figure (circled) for scale.

Dépôts de graviers résultant d'une ou plusieurs débâcles glaciaires, accumulés en aval du Lac glaciaire Skykomish, au-dessus de la vallée de North Fork Tolt River (Booth, 1986b). Les plus gros blocs mesurent $3 \mathrm{~m}$ de diamètre.

Sufficient reduction of basal drag can be achieved by allowing larger clasts to plough along the bed as they melt out. To allow ploughing, however, the strength of the subglacial sediment must be substantially lower than if the full weight of the ice rested on the bed sediments. Based on the reconstructed thickness of the ice sheet, a reduction of at least $90 \%$ is required and could have occurred only by a commensurate increase in the subglacial water pressure (Brown et al., 1987). Pervasive till deformation is also a possible mechanism for reduced drag and requires even greater water pressures (see below). Thus under any explaination for the rapid reconstructed sliding rates, the ice lobe must, have been nearly floating.

\section{Subglacial Water Pressure in the Substrate}

The generation of high subglacial water pressures has been modeled in a number of settings using a variety of techniques (e.g., Boulton et al., 1974; Boulton and Jones, 1979; Shoemaker, 1986). In the subglacial environment, high pressures can result from either transient loading, by advance of the ice margin over saturated sediment, or by steady-state production of basal meltwater within the ice-sheet interior. Using the general solutions for groundwater flow based on the anal- ogy with heat conduction (Bredehoeft and Hanshaw, 1968; Hanshaw and Bredehoeft, 1968), the transient condition results in a zone of influence of only a few tens of meters in width (Booth, 1984b). The steady-state condition, however, is more significant to the glacier as a whole.

The basis of any model of water movement in subglacial sediment is relatively simple. Assuming a source of basal melting only, water enters the till layer at a rate $\mathrm{q}_{\mathrm{o}}$ (the volume per unit time per unit area) and drains into a continuous sub-till aquifer of high (but finite) permeability $\mathrm{k}_{\mathrm{s}}$. In the Puget Lowland, this aquifer layer corresponds to sand-dominated outwash deposits that are widespread beneath the overlying till of the last glaciation (Liesch et al., 1963; Garling and Molenaar, 1965; Luzier, 1969). The meltwater is assumed to enter this highpermeability layer along its entire length $x$, from $x=0$ at the glacier terminus to $x=L$, the total glacier length. The total horizontal flux of water through this layer per unit width is therefore the product of $q_{o}$ and $L-x$, and the flux per unit area of aquifer is $q_{0}(L-x) / D$, where $D$ is the aquifer thickness. Integrating Darcy's Law,

$$
q=k_{s}\left(\frac{d p}{d x}\right)
$$

with the boundary condition that the pore pressure drops to zero at the terminus, yields:

$$
p=\frac{q_{o}}{D k_{s}} \times \frac{L x-x^{2}}{2}
$$

where $q$ is the local water flux through a unit area of aquifer and $p$ is the pore pressure at position $x$. Using values appropriate to the Puget lobe of $\mathrm{q}_{\mathrm{o}}=0.05 \mathrm{~m} / \mathrm{a}, \mathrm{D}=100 \mathrm{~m}, \mathrm{k}_{\mathrm{s}}=$ $1 \times 10^{-4} \mathrm{~m} / \mathrm{sec}$, and $\mathrm{L}=200 \mathrm{~km}$ (Rothlisberger, 1968; Olmstead, 1969; Booth, 1984b, 1986a), calculated values of p exceed the overburden pressure for all $x>0$. This condition is physically impossible: so groundwater flow alone cannot even drain the basal meltwater, let alone the much greater volume of surface meltwater that may also have reached the glacier bed.

This simple conclusion of basal meltwater movement results from the size of the Puget lobe, its high sliding velocity, and the consequent high flux of meltwater that would be required to drain through the subglacial aquifer. The assumptions are conservative, because any discontinuity or thinning of the aquifer, or substantially lower till permeability to impede the entry of subglacial meltwater into this aquifer, would further amplify the result. Conversely, the groundwater flow could drain the net production of meltwater only by increasing the presumed permeability of the outwash to values that nowhere have been reported in the region, or by reducing the total length of the ice sheet (L) by an order of magnitude or more, appropriate to much shorter valley glaciers. Equivalent conditions of subglacial water flowing at or near the overburden pressure also have been inferred (Alley et al., 1987) and recently observed (Engelhardt et al., 1990) at the base of Ice Stream B in Antarctica, a temperate-based glacier with remarkably similar parameters to those of the Puget lobe (total overbur- 
den $=9 \mathrm{MPa}$, basal shear stress $=50 \mathrm{kPa}$, and a largely softsediment bed).

\section{Effect of subglacial tunnels on pore-water pressure}

Because most of the meltwater production cannot be drained through the substrate, pressurized subglacial drainage must occur. The flow is likely to be concentrated into channels at the glacier bed (Stenborg, 1968; Shreve, 1972; Walder and Hallet, 1979). The pressure in these channels must be lower than the overburden, however, to allow fresh ice to replace the ice meiting off the tunnel walls. Thus the presence of tunnels reduces the pore pressure in subglacial sediments otherwise predicted by simple hydrostatics. This effect was investigated by Lliboutry (1983), with a major influence predicted from the influx of warm groundwater and the consequent increase in tunnel melting rate. This condition is judged highly unlikely beneath an extensive ice sheet.

Two other factors, however, are more relevant to porepressure reduction in tunnels. First is the reduction in pressure from potential energy losses from the flowing water, resulting in melting of the tunnel walls. This effect reduces pore pressures in the ice-sheet interior by only a few percent from that of the net overburden (Fig. 13a). This reduction becomes more significant within a few kilometers of the terminus, however, where the tunnel melt rate can exceed the closure rate and the water pressure drops to zero (Fig. 13b). This effect was further investigated by Hooke (1984), who developed a relationship between the depressurizing of tunnels and the water discharge, bed slope, and ice thickness. Where bed slopes are low, zeropressure tunnels are predicted with his formulation beneath Puget-lobe ice thicknesses less than about $200 \mathrm{~m}$.

A related factor in water-pressure reduction, the seasonal drainage of tunnels near the ice margin (Mathews, 1964; Lliboutry, 1983), can also result in a local, transient reduction of pore-water pressure that may reach farther upglacier than steady-state drainage. Propagating through the surrounding sediment, each pressure drop would raise the effective normal stress on the subglacial sediments (Booth, 1984b). Any effect will be localized, however, within a few kilometers of the ice margin, where viscous deformation of the relatively thin ice is too slow to close tunnels rapidly at the end of the melt season.

Thus slower flow rates under thinner ice allow the water pressure in tunnels to decline towards the terminus. The effective normal stress, the difference between the total ice overburden and the basal water pressure, will therefore increase towards the ice margin, because the water pressure drops downglacier more rapidly than the ice sheet thins (Fig. 13b; see also Boulton and Paul, 1976).

\section{Geologic evidence of subglacial water pressures}

The history of water-pressure fluctuations in sediment can be inferred only under certain conditions (Shaw and Gilbert, 1990). More commonly, only the maximum effective normal stress ever applied to the sediment is recorded, typically by the overconsolidation of clay. If the maximum thickness of ice is known, then the difference between total and effective normal stress represents the minimum water pressure in the sediment during loading.
In the Puget Lowland, such data are locally available. Measured overconsolidation data in clay sediment, widely distributed as preglacial and proglacial lacustrine deposits, were compiled by Laprade (1982). All were from the Seattle area, where the ice at maximum applied a total overburden pressure of about $10 \mathrm{MPa}$. Maximum measured overconsolidation values, however, were $3 \mathrm{MPa}$ with the great majority under $1.5 \mathrm{MPa}$. Thus minimum pore-water pressures were on the order of $80-90 \%$ of the maximum ice overburden and could have been even higher during most of the ice occupation.

Brown et al. (1987) also argue for high subglacial water pressure from the nature of observed shearing of subglacial sediment. Local deformation of till in the Puget Lowland is evident by numerous exposures of fractured, swirled, pinched, and boudinaged layers. Based on measured strength parameters in till, showing cohesion values near zero and internal friction angles between 30 and $40^{\circ}$ (Linell and Shea, 1960), effective normal stresses of less than about $100 \mathrm{kPa}$ would be necessary for sediment deformation under the $50-\mathrm{kPa}$ basal shear stress applied by the ice. This in turn requires pore-water pressures of about $99 \%$ of the total ice overburden in the middle of the Puget lobe, for as long as sediment deformation occurred. On rheologic grounds, Alley (1989) also argues for very low effective normal stresses (about $10 \mathrm{kPa}$ ) wherever the glacier bed is underlain by soft sediment and subglacial water flow is not channelized. In the Puget Lowland, only near the ice margin would episodic emptying of subglacial tunnels, allowed by slow deformation of thin ice, have reduced water pressures and locally inhibited the sediment shearing so commonly observed.

\section{DISCRIMINATION OF "INTERIOR" AND "MARGINAL" ZONES}

An intuitive division has often been implied by the division of an ice sheet into "interior" and "marginal" zones (e.g., Smalley and Unwin, 1968; Mickelson et al., 1979; Mooers, 1990). The reconstructed thermal regime of the Laurentide Ice Sheet has motivated much of this discussion, because the processes beneath a frozen toe are likely to differ greatly from those beneath the temperate basal ice of the interior. Yet even beneath an ice sheet that was temperate throughout, such as the Puget lobe, the discrimination is warranted and useful.

Within the interior zone of the Puget lobe, and probably most other temperate ice sheets with a high mass flux associated with a maritime climate, water derived from basal melting alone is ample to produce subglacial water pressures approaching the ice pressure. Irrespective of the spatial variability in sliding velocity, substrate permeability, and tunnel location, very high basal pore pressures should be pervasive. Thus both effective normal stress and till strengths should be uniformly low, because the slow drainage of basal meltwater swamps all potential sources of variability, leaving the bulk of the icecovered terrain under nearly uniform conditions. Even with fortuitously improved subglacial drainage, the variability of measured till properties should be much lower than the full range of overburden loads applied by the overlying ice (e.g., van Gelder et al., 1990). 

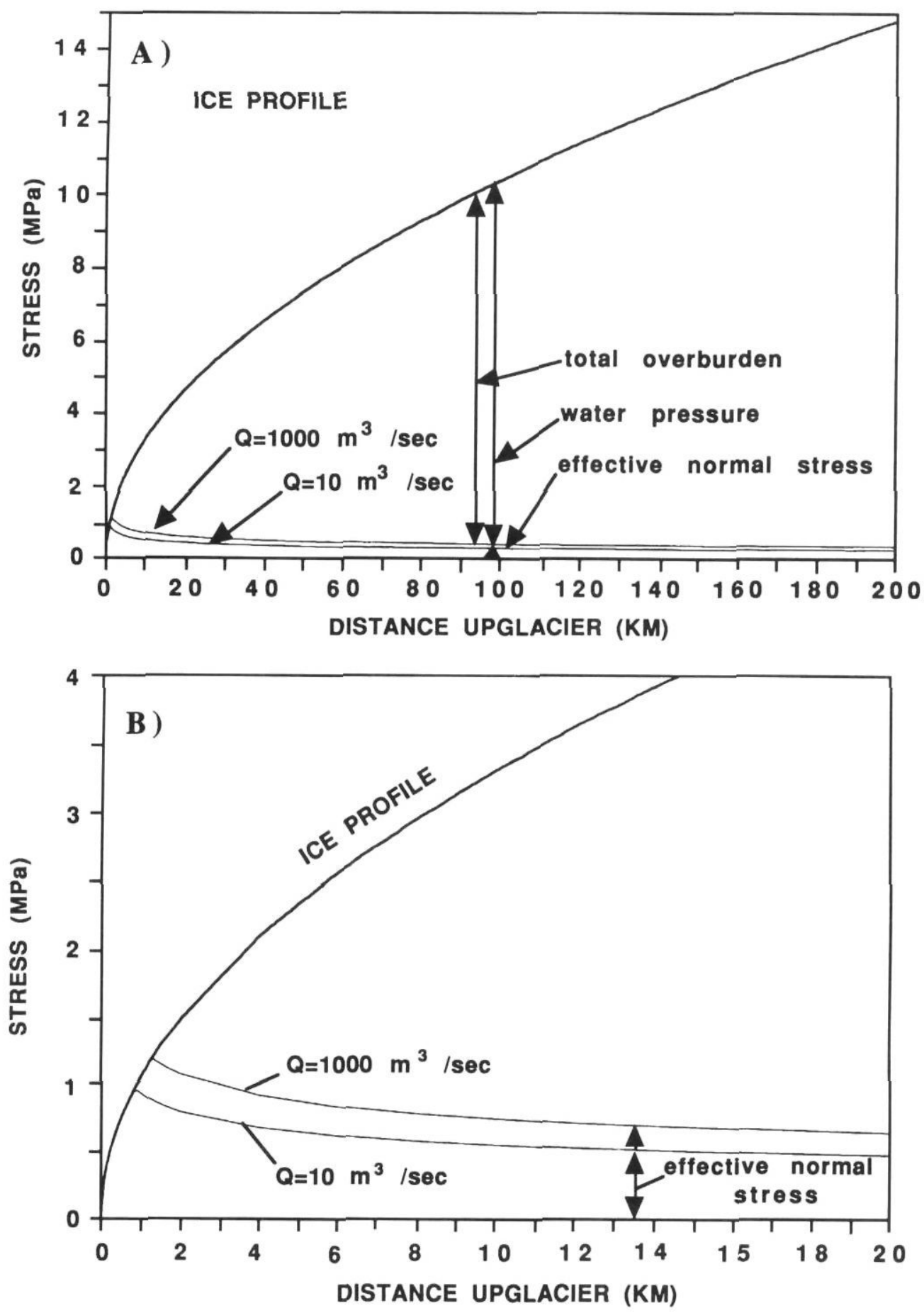

FIGURE 13. A. Comparison of effective and total overburden stresses under the centerline profile of the Puget Lobe, based on Lliboutry (1983) and available data on basal meltwater production and subglacial sediment properties. Over the vast majority of the ice lobe's interior, effective stresses are uniformly low with very little sensitivity either to position or to subglacial tunnel discharges, graphed for two sample discharges that bracket likely tunnel discharges beneath the ice lobe. B. Expanded scale of the marginal zone of the ice lobe in Figure 13a. The effective stress rises to equal the overburden only within $2 \mathrm{~km}$ of the margin, achieving a maximum value of about $1 \mathrm{MPa}$. Seasonal drainage of tunnels, if active farther upglacier, could locally and episodically raise the effective stress by perhaps a factor of 3. Retreat of an active ice margin would eventually subject the entire interior zone to the same magnitude of overconsolidation.

A. Comparison entre les contraintes réelles et totales sous le lobe de Puget, fondée sur Lliboutry (1983) et les données disponibles sur l'apport en eau de fonte et les propriétés des sédiments sousglaciaires. Sur la plus grande partie de l'intérieur du lobe, les contraintes réelles sont uniformément faibles et peu sensibles à l'emplacement ou aux débits des tunnels sous-glaciaires calculés pour deux types de débits vraisemblablement représentatifs des débits des tunnels situés sous le lobe. B. Zone marginale du lobe glaciaire à plus grande échelle que dans A. La contrainte réelle augmente pour devenir égale à la couverture de glace à seulement $2 \mathrm{~km}$ de la marge et atteindre une valeur maximale de $1 \mathrm{MPa}$. Le drainage saisonnier des tunnels, s'il se fait plus en amont, pourrait localement et à l'occasion augmenter la contrainte réelle par peut-être un facteur de 3. Le recul d'une marge glaciaire active pourrait en fin de compte soumettre toute la zone interne à une surconsolidation des sédiments de même amplitude.
Farther downglacier, pore pressures decrease more rapidly than the ice thins. This relaxation, however, is not uniform the intrinsic spatial variability of the substrate and the subglacial water system becomes progressively more significant. Areas of the bed near to tunnels, or underlain by thicker or more permeable sediment, will experience comparatively greater porepressure declines, and thus greater increases in effective normal stresses, than other areas under equivalent thicknesses of ice but with less favorable conditions for drainage. Within a few kilometers of the margin, pressure in subglacial tunnels may drop to atmospheric levels for a substantial fraction of each year, allowing overconsolidation of the bed that is adjacent to the empty tunnel by the full ice overburden load.

This transition between near-uniform conditions upglacier and spatially and temporally variable conditions downglacier provides a physical basis for the discrimination of "interior" and "marginal" zones. For the Puget lobe, the calculated rate of 
pore- and tunnel-pressure dissipation (Fig. 13), together with typical measured overconsolidation of 1-3 MPa (Laprade, 1982), suggest that the marginal zone is less than $10 \mathrm{~km}$ wide. This zone includes less than $3 \%$ of the total length of the Puget lobe; it is the only region where basal conditions were significantly heterogeneous, and unpredictably so. Upglacier, conditions are much more uniform. Across the Puget Lowland, and presumably other glaciated areas as well, the consequences of this uniformity include the low strength of subglacial till, its homogeneity over hundreds of square kilometers (see also Karrow, 1976), and the potential for extensive ice-bed separation with abundant interbedded water-worked sediment in the basal deposits (see, for example, Easterbrook, 1968; Booth, 1990; also Shaw, 1979; Eyles et al., 1982).

The non-uniform conditions inferred for the marginal zone should migrate along with the backwasting of an active ice front. They may therefore affect every part of a till-covered region. Because effective stresses are higher near the ice margin, this state will be superimposed over sediments that were deposited, under a very different stress regime, in the ice-sheet interior. What is exposed today, throughout the Puget Lowland and perhaps in most glaciated regions, are sediments with properties inherited from this last-stage retreat. They do not necessarily reflect conditions during the vast majority of ice occupation.

\section{CONCLUSIONS}

The geologic record of glaciation reflects a variety of physical processes by the agents of ice and water. Detailed observations can provide the chronology, the location, and perhaps some constraints on the processes by which these agents accomplished their work. Yet to interpret more fully their action, their relative importance, and their effect on the landscape, a physical reconstruction of the ice-water system is necessary.

The Puget lobe of the Cordilleran Ice Sheet offers a sufficient geologic record to accomplish this reconstruction. Its extent is deduced from ice limits and flow-direction indicators; by analogy to modern maritine glaciers, its mass balance can be estimated as well. Both ice and water fluxes were vigorous, with sliding velocities in excess of $500 \mathrm{~m} / \mathrm{a}$ and water discharges of nearly $1 \times 10^{11} \mathrm{~m}^{3} / \mathrm{a}$ (about $3000 \mathrm{~m}^{3} / \mathrm{sec}$ ).

The flow of this subglacial water produced distinctive landforms, particularly near the lateral margins of the ice lobe's ablation zone. Where analyzed in detail, a roughly dendritic channel pattern, etched into both till and bedrock, drains the interior part of these near-marginal areas. Flow was downglacier and margin-ward, following the regional slope of the icesheet surface, and flowed up and down the bed topography as dictated by the gradients in hydraulic head at the base of the ice. Near to the eastern ice margin, a single channel of much larger size collected both interior meltwater and nonglacial runoff from the adjacent mountains. It drained subglacially and episodically, with ice-dammed lakes impounded in the adjacent mountain valleys releasing their water to this submarginal channel as episodic jokulhlaups.

The rate of production of basal meltwater, coupled with the longitudinal extent of the Puget lobe, generated very high water pressure at the base of the ice sheet, sufficient to establish near-hydrostatic conditions over most of the interior zone. Till strength was very low, suggesting extensive ice-bed separation under an essentially floating glacier.

Close to the ice margin, the release of water pressure via subglacial tunnels was sufficient to raise effective normal stresses to significant fractions of the total ice overburden. The recorded overconsolidation of sediments, typically about onetenth of the ice-maximum overburden, reflects the marginal conditions of moderately thinner ice but much lower water pressures. This correspondence emphasizes the importance of upglacier migration of the marginal zone during ice retreat, when the conditions unique to the outermost few kilometers of an ice sheet can be superimposed over sediments with a much different depositional and deformational history.

The Puget lobe is somewhat unusual amongst the vanished Pleistocene ice sheets, in that fortuitous regional topography has recorded its shape and extent in considerable detail. Yet the physical behavior of the ice and water here is no different than beneath any other temperate ice sheet. Thus many of these results, particularly the pattern of subglacial meltwater flow and the variability of subglacial pore-water pressures, should be readily transferrable to other glaciers. Indeed, these approaches were developed from, and have been applied to, modern glaciers for decades. What Pleistocene glaciers, in contrast to their modern successors, lack in measurable parameters of the ice they gain in providing unrestricted access to their beds. An analysis of their physical processes, such as offered here for the Puget lobe, provides some of the tools to use more fully that information.

\section{ACKNOWLEDGMENTS}

The development of these ideas have benefitted greatly from discussions with Bernard Hallet, Charles Raymond, Steven Porter, Richard Waitt, Jr., and Rowland Tabor. Most of the original field work occurred while mapping bedrock and surficial deposits for the U.S. Geological Survey, and later for King County, throughout the south-çentral and eastern Puget Lowland. Bernard Hallet provided countless suggestions on earlier drafts of this manuscript, and his assistance is gratefully recorded here. Dr. J. Begét and L. Jackson have reviewed the paper and provided useful suggestions.

\section{REFERENCES}

Alley, R. B., 1989. Water-pressure coupling of sliding and bed deformation: I. Water system. Journal of Glaciology, 35: 108-118.

Alley, R. B., Blankenship, D. D., Bentley, C. R. and Rooney, S. T., 1987. Till beneath Ice Stream B: 3. Till deformation: evidence and implications. Journal of Glaciology, 92 (B9): 8921-8929.

Anderson, F. E., 1968. Seaward terminus of the Vashon continental glacier in the Strait of Juan de Fuca. Marine Geology, 6: 419-438.

Armstrong, J. E., Crandell, D. R., Easterbrook, D. J. and Noble, J. B., 1965. Late Pleistocene stratigraphy and chronology in southwestern British Columbia and northwestern Washington. Geological Society of America Bulletin, 76: 321-330.

Armstrong, J. E. and Clague, J. J., 1977. Two major Wisconsin lithostratigraphic units in southwest British Columbia. Canadian Journal of Earth Sciences, 14: $1471-1480$. 
Baker, V. R., 1973. Paleohydrology and sedimentology of Lake Missoula flooding in eastern Washington. Geological Society of America Special Paper $144,79 \mathrm{p}$.

Begét, J. E., 1986. Comment on "Outburst Floods from Glacial Lake Missoula" by G. K. C. Clark, W. H. Mathews and R. T. Pack. Quaternary Research, 25: $136-138$

Barnosky, C. W., Anderson, P. M. and Bartlein, P. J., 1987. The northwestern U.S. during deglaciation; vegetational history and paleoclimatic implications, p. 289-321. In W. F. Ruddiman and H. E. Wright, Jr., eds., North America and Adjacent Oceans During the Last Deglaciation, vol. K-3 of The Geology of North America. The Geological Society of America, Boulder, Colorado, $501 \mathrm{p}$.

Blankenship, D. D., Bentley, C. R., Rooney, S. T. and Alley, R. B., 1987. Till beneath Ice Stream B: 1. Properties derived from seismic travel times. Journal of Glaciology, 92 (B9): 8903-8911.

Booth, D. B., 1984a. Ice-sheet reconstruction and erosion by subglacial meltwater in the eastern Puget Lowland, Washington. Abstracts with Programs, Annual Meeting, Geological Society of America, 16: 450.

1984b. Glacier dynamics and the development of glacial landforms in the eastern Puget Lowland, Washington. Seattle, Ph.D. thesis, University of Washington, $217 \mathrm{p}$.

1986a. Mass balance and sliding velocity of the Puget lobe of the Cordilleran ice sheet during the last glaciation. Quaternary Research, 29 : 269-280.

1986b. The formation of ice-marginal embankments into ice-dammed lakes in the eastern Puget Lowland, Washington, U.S.A., during the late Pleistocene. Boreas, 15: 247-263.

1987. Timing and processes of deglaciation along the southern margin of the Cordilleran ice sheet, p. 71-90. In W. F. Ruddiman and H. E. Wright, Jr., eds., North America and Adjacent Oceans During the Last Deglaciation, vol. K-3 of The Geology of North America. The Geological Society of America, Boulder, Colorado, $501 \mathrm{p}$.

1990. Surficial geology of the Skykomish and Snoqualmie Rivers area, Snohomish and King Counties, Washington. U.S. Geological Survey Miscellaneous Investigations Map I-1745, scale 1:50,000.

Boulton, G. S. and Jones, A. S., 1979. Stability of temperate ice caps and ice sheets resting on beds of deformable sediment. Journal of Glaciology, 24: 29-44.

Boulton, G. S., Dent, D. L. and Morris, E. M., 1974. Subglacial shearing and crushing and the role of water pressures in tills from southeast Iceland. Geographiska Annaler, 56A: 135-145.

Boulton, G. S. and Paul, M. A., 1976. The influence of genetic processes on some geotechnical properties of glacial tills. Quarterly Journal of Engineering Geology, 9: 159-194.

Bredehoeft, J. D. and Hanshaw, B. B., 1968. On the maintenance of anomalous fluid pressure: I. Thick sedimentary sequences. Geological Society of America Bulletin, 79: 1097-1106.

Bretz, J H., 1913. Glaciation of the Puget Sound region. Washington Geological Survey Bulletin 8, $244 \mathrm{p}$.

Brown, N. E., Hallet, B. and Booth, D. B., 1987. Rapid soft bed sliding of the Puget glacial lobe. Journal of Geophysical Research, 92 (B9): 8985-8997.

Chrzastowski, M. J., 1980. Submarine features and bottom configuration in the Port Townsend Quadrangle, Puget Sound region, Washington. U.S. Geological Survey Open-File Map 80-14, scale 1:50,000.

Clague, J. J., 1975, Sedimentology and paleohydrology of late Wisconsinan outwash, Rocky Mountain trench, Southeastern British Columbia, p. 223-237. In A. V. Jopling and B. C. McDonald, eds., Glaciofluvial and Glaciolacustrine Environments. Society of Economic Paleontologists and Minerologists, Special Publication 23, $320 \mathrm{p}$.

1981. Late Quaternary geology and geochronology of British Columbia, Part 2. Geological Survey of Canada, Paper 80-35, $41 \mathrm{p}$.

Clague, J. J. and Mathews, W. H., 1973. The magnitude of jokulhlaups. Journal of Glaciology, 12: 501-504.
Clapperton, C. M., 1968. Channels formed by the superimposition of glacial meltwater streams, with special reference to the East Cheviot Hills, Northeast England. Geographiska Annaler, 50A: 207-220.

Clarke, G. K. C., Mathews, W. H. and Pack, R. T., 1984. Outburst floods from Glacial Lake Missoula. Quaternary Research, 22: 289-299.

Crandell, D. R., Mullineaux, D. R. and Waldron, H. H., 1958. Pleistocene sequence in the southeastern part of the Puget Sound lowland, Washington. American Journal of Science, 256: 384-397.

Dahl, R., 1965. Plastically sculptured detail forms on rock surfaces in northern Nordland, Norway. Geographiska Annaler, 47A: 83-140.

Easterbrook, D. J., 1963. Late Pleistocene glacial events and relative sea level changes in the northern Puget Lowland, Washington. Geological Society of America Bulletin, 74, 1465-1484.

1968. Pleistocene stratigraphy of Island County, Washington. Washington State Water-Supply Bulletin no. 25, 34 p.

Easterbrook, D. J., Crandell, D. R. and Leopold, E. B., 1967. Pre-Olympia Pleistocene stratigraphy and chronology in the central Puget Lowland, Washington. Geological Society of America Bulletin, 78: 13-20.

Ehlers, J., 1981. Some aspects of glacial erosion and deposition in northern Germany. Annals of Glaciology, 2: 143-146.

Engelhardt, H., Humphrey, N. and Kamb, B., 1990. Borehole geophysical observations on Ice Stream B, Antarctica. Eos, 71: 1302.

Eyles, N., Sladen, J. and Gilroy, S., 1982. A depositional model for stratigraphic complexes and facies superimposition in lodgement tills. Boreas, 11: 317-333.

Garling, M. E., Molenaar, D., Denburgh, A. S. and Fiedler, G. H., 1965. Water resources and geology of the Kitsap Peninsula and certain adjacent islands. Washington State Water-Supply Bulletin no. 18, 309 p.

Gustavson, T. C. and Boothroyd, J. C., 1987. A depositional model for outwash, sediment sources, and hydrologic characteristics, Malaspina Glacier, Alaska: a modern analog for the southeastern margin of the Laurentide ice sheet. Geological Society of America Bulletin, 99: 187-200.

Hanshaw, B. B. and Bredehoeft, J. D., 1968. On the maintenance of anomalous fluid pressure: II. Source layer at depth. Geological Society of America Bulletin, 79: 1107-1122.

Heusser, C. J., 1973. Environmental sequence following the Fraser advance of the Juan de Fuca lobe, Washington. Quarternary Research, 3: 284-306.

Hooke, R. LeB., 1984. On the role of mechanical energy in maintaining subglacial water conduits at atmospheric pressure. Journal of Glaciology, 30: 180-188.

International Association of Hydrological Sciences (IAHS), 1977. Fluctuations of glaciers, vol. 3. International Commission on Snow and Ice, Paris, IAHSUNESCO, $269 \mathrm{p}$.

Karrow, P. F., 1976. The texture, minerology, and petrography of North American tills, p. 83-98. In R. F. Legget, ed., Glacial Till, an Interdisciplinary Study. Royal Society of Canada, Ottawa, $412 \mathrm{p}$.

Kutsbach, J. E., 1987, Model simulations of the climatic patterns during the deglaciation of North America, p. 425-446. In W. F. Ruddiman and H. E. Wright, Jr., eds., North America and Adjacent Oceans During the Last Deglaciation, vol. K-3 of The Geology of North America. The Geological Society of America, Boulder, Colorado, $501 \mathrm{p}$.

Laprade, W. T., 1982. Geologic implications of pre-consolidated pressure values, Lawton Clay, Seattle, Washington. Proceedings, 19th Annual Engineering Geology and Soils Engineering Symposium, Idaho State University, Pocatello, p. 303-321.

Liesch, B. A., Price, C. E. and Walters, K. L., 1963. Geology and ground-water resources of northwestern King County, Washington. Washington State Water-Supply Bulletin no. 20, 241 p.

Linell, K. A. and Shea, H. F., 1960. Strength and deformation characteristics of various glacial tills in New England. American Society of Civil Engineers Research Conference on the Shear Strength of Cohesive Soils, Boulder, Colorado, p. 275-314. 
Lliboutry, L., 1983. Modification to the theory of intraglacial waterways for the case of subglacial ones. Journal of Glaciology, 29: 216-226.

Luzier, J. E., 1969. Geology and ground-water resources of southwestern King County, Washington. Washington State Water-Supply Bulletin no. 28, 260 p.

Mackin, J. H., 1941. Glacial geology of the Snoqualmie-Cedar area, Washington. Journal of Geology, 49: 449-481.

Mannerfelt, C. M., 1949. Marginal drainage channels as indicators of the gradients of Quaternary ice caps. Geographiska Annaler, 31: 194-199.

Mathews, W. H., 1974. Surface profile of the Laurentide ice sheet in its marginal areas. Journal of Glaciology, 13: 37-43.

1964. Water pressure under glaciers. Journal of Glaciology, 5: 235-240.

Meier, M. F., Tangborn, W. V., Mayo, L. R. and Post, A., 1971. Combined ice and water balances of Gulkana and Wolverine glaciers, Alaska, and South Cascade glacier, Washington, 1965 and 1966 hydrologic years. U.S. Geological Survey Professional Paper 715A, 23 p.

Mickelson, D. M., Acomb, L. J. and Edil, T. B., 1979. The origin of preconsolidated and normally consolidated tills in eastern Wisconsin, U.S.A., p. 179-187. In C. Schlüchter, ed., Moraines and Varves. A. A. Balkema, Rotterdam, $441 \mathrm{p}$.

Mooers, H. D., 1990. A glacial-process model: The role of spatial and temporal variations in glacier thermal regime. Geological Society of America Bulletin, 102: $243-251$.

Mullineaux, D. R., Waldron, H. H. and Rubin, M., 1965. Stratigraphy and chronology of late interglacial and early Vashon glacial time in the Seatte area, Washington. U.S. Geological Survey Bulletin 1194-O, 10 p.

Nye, J. F., 1976. Water flow in glaciers: jokulhlaups, tunnels and veins. Journal of Glaciology, 17: 181-207.

Olmstead, T. L., 1969. Geotechnical aspects and engineering properties of glacial till in the Puget Lowland, Washington. Proceedings, 7th Annual Engineering Geology and Soils Engineering Symposium, Moscow, Idaho, p. 223-233.

Paterson, W. S. B., 1981. The Physics of Glaciers. Pergamon Press, Oxford, $380 \mathrm{p}$.

Pessl, F., Jr., Dethier, D. P., Booth, D. B. and Minard, J. P., 1987. Surficial geologic map of the Port Townsend 30 -minute by 60 -minute quadrange, Washington. U.S. Geological Survey Miscellaneous Investigations Map I-1198, scale 1:100,000.

Pierce, K. L., 1979. History and dynamics of glaciation in the northern Yellowstone National Park area. U.S. Geological Survey Professional Paper 729F, 90 p.

Porter, S. C., 1976. Pleistocene glaciation in the southern part of the North Cascade Range, Washington. Geological Society of America Bulletin, 87: 61-75.

_ 1977. Present and past glaciation threshold in the Cascade Range, Washington, U.S.A.: Topographic and climatic controls. Journal of Glaciology, 18: 101-116.

Porter, S. C., Pierce, K. L. and Hamilton, T. D., 1983. Late Wisconsin mountain glaciation in the western United States, p. 71-111. In H. E., Wright, Jr., ed., volume 1 of Late Quaternary Environments of the United States (S. C. Porter, ed.). University of Minnesota Press, Minneapolis, $407 \mathrm{p}$.

Post, A. S. and Mayo, L. R., 1971. Glacier dammed lakes and outburst floods in Alaska. U.S. Geological Survey Hydrologic Investigations Atlas 559, 3 sheets.
Ridky, R. W. and Bindschadler, R. A., 1990. Reconstruction and dynamics of the late Wisconsin "Ontario" ice dome in the Finger Lakes region, New York. Geological Society of America Bulletin, 102: 1055-1064.

Rigg, G. B. and Gould, H. R., 1957. Age of Glacier Peak eruption and chronology of postglacial peat deposits in Washington and surrounding areas. American Journal of Science, 255: 341-363.

Robin, G. de Q., 1967. Surface topography of ice sheets. Nature, 215: 1029-1032.

Rothlisberger, H., 1968. Erosive processes which are likely to accentuate or reduce the bottom relief of valley glaciers. International Association of Scientific Hydrologists, 79: 87-97.

1972. Water pressure in intra- and subglacial channels. Journal of Glaciology, 11: 177-203.

Sharpe, D. R. and Shaw, J., 1989. Erosion of bedrock by subglacial meltwater, Cantley, Quebec. Geological Society of America Bulletin, 101: 1011-1020.

Shaw, J., 1979. Genesis of Sveg tills and Rogen moraines of central Sweden: A model of basal melt-out. Boreas, 8: $409-415$.

Shaw, J. and Gilbert, R., 1990. Evidence for large-scale subglacial meltwater flood events in southern Ontario and northern New York State. Geology, 18: 1169-1172.

Shoemaker, E. M., 1986. Subglacial hydrology for an ice sheet resting on a deformable aquifer. Journal of Glaciology, 32: 20-30.

Shreve, R. L., 1972. Movement of water in glaciers. Journal of Glaciology, 11: 205-214.

1985. Esker characteristics in terms of glacier physics, Katahdin esker system, Maine. Geological Society of America Bulletin, 96: 639-646.

Sissons, J. B., 1963, The glacial drainage system around Carlops, Peeblesshire. Transactions of the Institute of British Geographers, 32: 95-111.

Smalley, I. J. and Unwin, D. J., 1968. The formation and shape of drumlins and their distribution and orientation in drumlin fields. Journal of Glaciology, 7: 377-390.

Stenborg, T., 1968. Glacier drainage connected with ice structure. Geographiska Annaler, 50A: 25-53.

Stone, K. H., 1963. Alaskan ice-dammed lakes. Association of American Geographers, Annals, 53: 332-349.

Sugden, D. E., 1979. Ice sheet erosion - a product of maximum conditions? Journal of Glaciology, 23: 402-404.

Thorson, R. M., 1980. Ice sheet glaciation of the Puget Lowland, Washington, during the Vashon stade. Quaternary Research, 13: 303-321.

1989. Glacio-isostatic response of the Puget Sound area, Washington. Geological Society of America Bulletin, 101: 1163-1174.

U. S. Geological Survey, 1983. U.S. Geological Survey water resources data, Washington, water year 1981, vol. 1, 337 p.

van Gelder, G., de Graff, L. W. S. and Schurink, E., 1990. Subglacial consolidation of fine-grained stratified sediment: a neglected tool in reconstructing ice-thickness in Pleistocene valley glaciers. Arctic and Alpine Research, 22: 329-340.

Walder, J. S. and Hallet, B., 1979. Geometry of former subglacial water channels and cavities. Journal of Glaciology, 23: 335-346.

Weertman, J., 1964. Rate of growth or shrinkage of non-equilibrium ice sheets. Journal of Glaciology, 5: 145-158.

Wilson, J. T., Falconer, G., Mathews, W. H. and Prest, V. K., 1958. Glacial map of Canada. Geological Association of Canada, scale 1:3,801,600. 